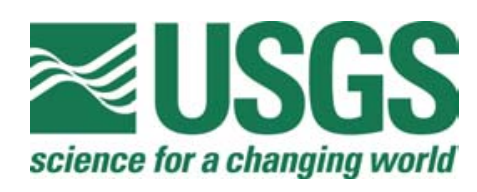

\title{
Chemical Analyses of Soils and Rocks From Two High Elevation Study Areas in Colorado
}

By William R. Miller, Richard F. Sanzolone, and Paul J. Lamothe

This report is preliminary and has not been reviewed for conformity with the U.S. Geological Survey editorial standards or with the North American Stratigraphic Code.

Any use of trade, firm, or product names is for descriptive purposes only and does not imply endorsement by the U.S. Government.

Open-File Report 2003-03-106

Denver, Colorado

U.S. Department of the Interior

U.S. Geological Survey 


\section{TABLE OF CONTENTS}

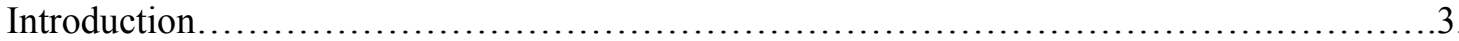

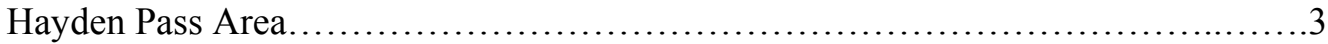

Pikes Peak Area.............................................................. 3

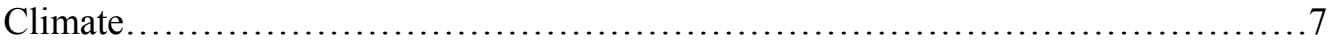

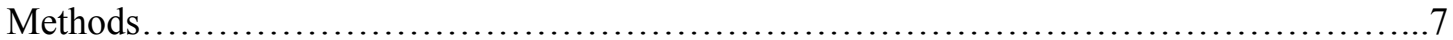

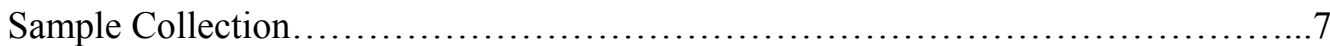

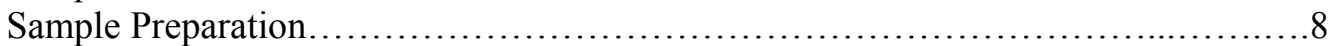

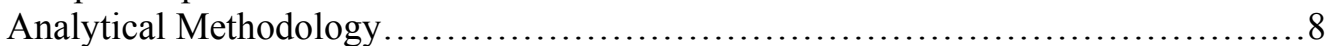

Total Elemental Composition........................................... 8

$\mathrm{MgCl}_{2}$ Extraction....................................................

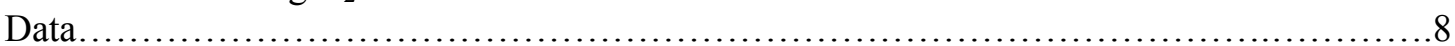

Hayden Pass Study Area....................................................... 8

Pikes Peak Study Area...................................................... 13

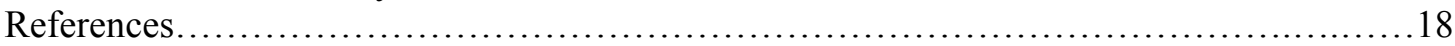

\section{Tables}

Table 1 Selected elements of soils from the Hayden Pass Area and Pikes Peak area...........10

Table 2 Selected elements of a $\mathrm{MgCl}_{2}$ extraction of soils from the Hayden Pass and

Pikes Peak study areas........................................................ 15

\section{Figures}

Figure 1. Map showing locations of the Hayden Pass and Pikes Peak study areas..............4

Figure 2. Map showing locations of soil and rock samples in the Hayden Pass area...........5

Figure 3. Map showing locations of soil and rock samples from Pikes Peak study area........6

Figure 4. Cartoon showing location of soils samples from the Hayden Pass study area........9

Figure 5. Cartoon showing location of soils samples from the Pikes Peak study area..........14

\section{Appendix}

Appendix 1. Chemical analysis of rocks from the Hayden Pass and Pikes Peak study area.....19

Appendix 2. Chemical analysis of soils from the Hayden Pass and Pikes Peak study areas....26

Appendix 3. Chemical analysis of the $\mathrm{MgCl}_{2}$ extracts of soils from Hayden Pass and 


\section{Introduction}

The winds aloft carry dust and aerosols across continents and oceans. If pollution is heavily concentrated in an area, downwind areas will be affected by the pollution. Examples of point sources of pollution with associated downwind contamination plumes are smelters and coal-burning power plants. Non-point sources such as industrial pollution in the Midwestern U.S. can lead to acid rain in downwind areas.

A preliminary investigation was carried out in Colorado to test if elements were being deposited at high elevations in two areas of Colorado, which form natural barriers to the winds. This investigation was designed to detect differences of element contents of soils collected on each side of a mountain ridge or peak. The assumption is that dust and aerosol-bearing winds buffet the high ridges and peaks of mountain ranges and some of the dust and aerosols will be deposited mostly on the windward side of the range. Soils formed in place on similar rock types would be elevated in some elements present in the dust and aerosols on the windward side of the ridge or peak relative to the leeward side. Two study areas were selected based on being located at high elevation and having similar geology on both sides of the ridge or peak. If rock composition is the same throughout the study area, soils, which are derived from the rocks and not transported, should have the same chemical composition on both sides of the ridge or peak without the added input from the winds aloft. The two areas selected are: 1) Hayden Pass, Sange de Cristo Range; and 2) Pikes Peak, Front Range (fig. 1). Both mountain ranges are oriented north south and form barriers to the winds aloft.

\section{Hayden Pass Study Area}

The Hayden Pass area (fig. 2) is located in the northern Sangre de Cristo Range in Colorado. The range is about 200 miles long and forms a north south barrier. The San Luis Valley borders the range to the west. Elevations of the study area range from 10,380 to 10,750 feet. Dominant vegetation is pine - Douglas fir forest. Annual precipitation ranges from 25 to 30 inches per year (Colorado Climate Center, 1984). The study area is underlain by Pennsylvanian Minturn Formation which consists of fan-delta deposits formed by alluvial fans which inter-finger with marine strata along the western edge of the central Colorado trough (Lindsey and others, 1985). Within the study area, the rocks consist of buff to reddish colored medium to coarse-grained sandstones formed from coalescing alluvial fans. The soils are developed in place and are not transported. They are derived from weathering of the underlying rock and are buff to reddish in color. The soils are thin, usually less than a couple of inches in depth and are lithosols. Organic matter is generally absent.

\section{Pikes Peak Study Area}

The Pikes Peak study area (fig. 3) is located in the Rampart Range, west of Colorado Springs. The Rampart Range is part of the Colorado Front Range. The peak forms a barrier to winds from all directions. Elevations in the study area range from 12,440 to 14,070 feet. The study area is located mostly in the alpine zone above timberline. Annual precipitation ranges from 25 to 30 inches per year (Colorado Climate Center, 1984). The study area is underlain by the Pikes Peak batholith. The $1.1 \mathrm{Ga}$ age (Marshall and DePaolo, 1982) composite batholith (Wobus and others, 1976) is an A- 


\section{Colorado}

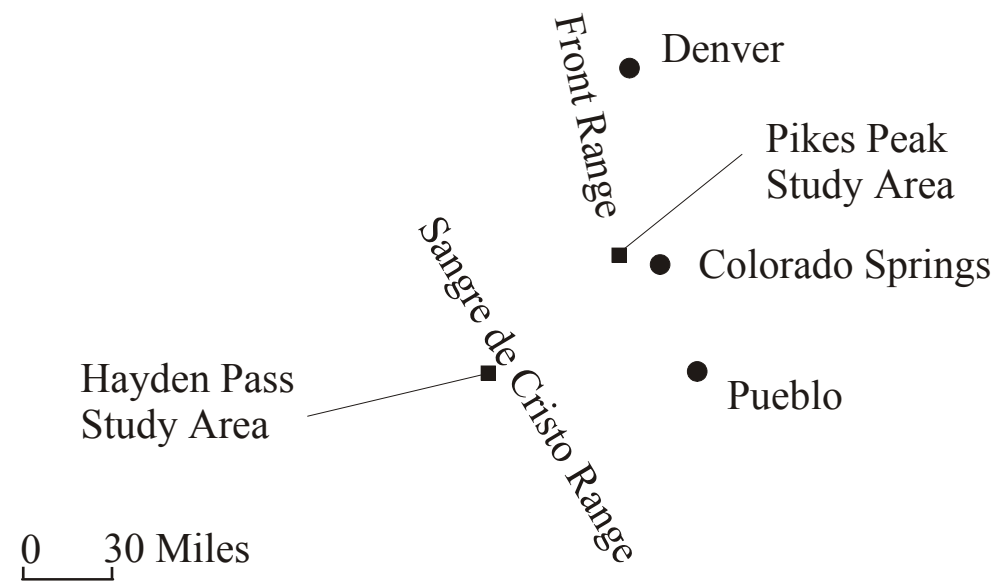

Figure 1. Map showing locations of the Hayden Pass and Pikes Peak Study Areas, Colorado 


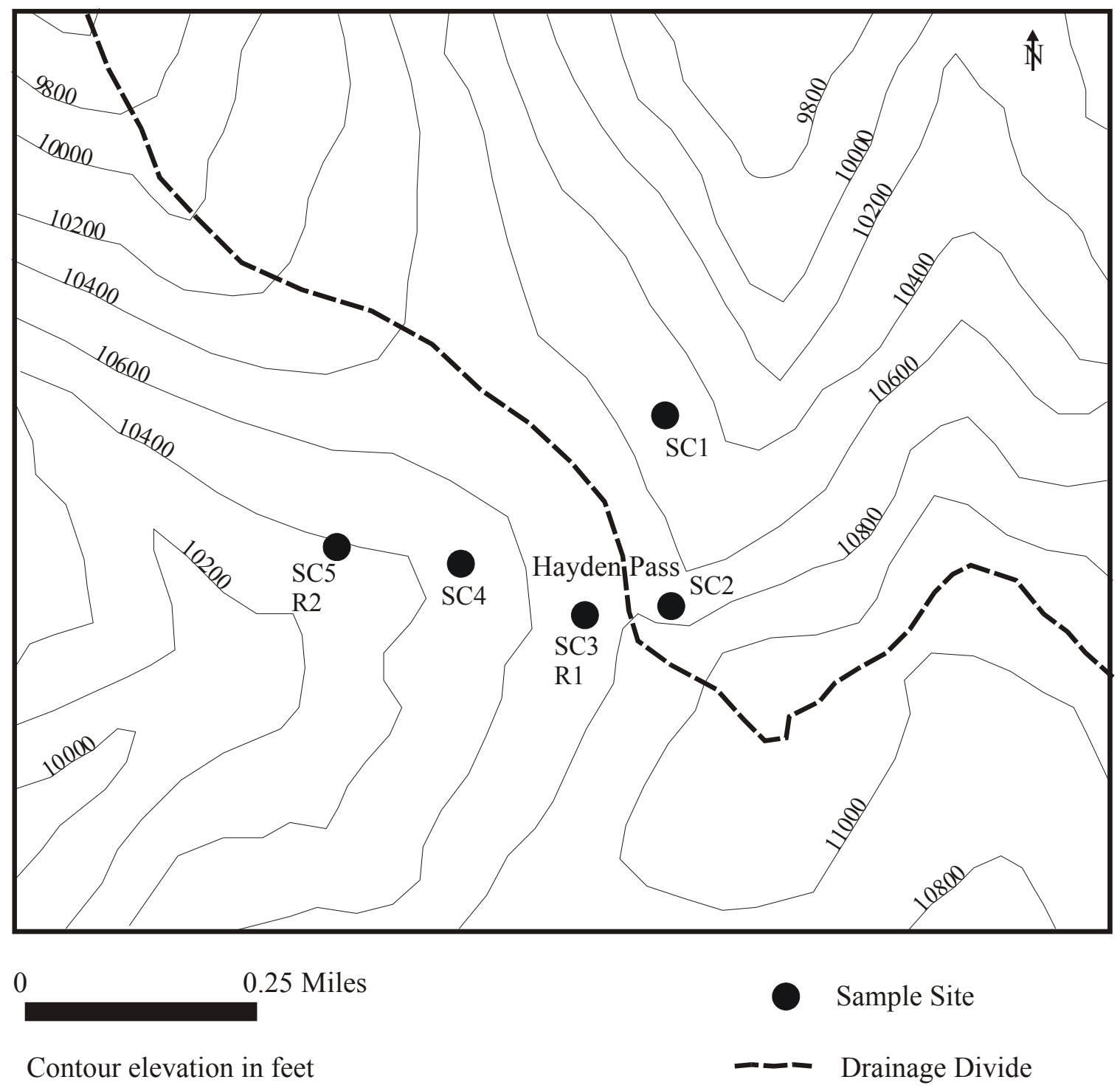

Figure 2. Map showing locations of soil and rock samples in the Hayden Pass study area. 


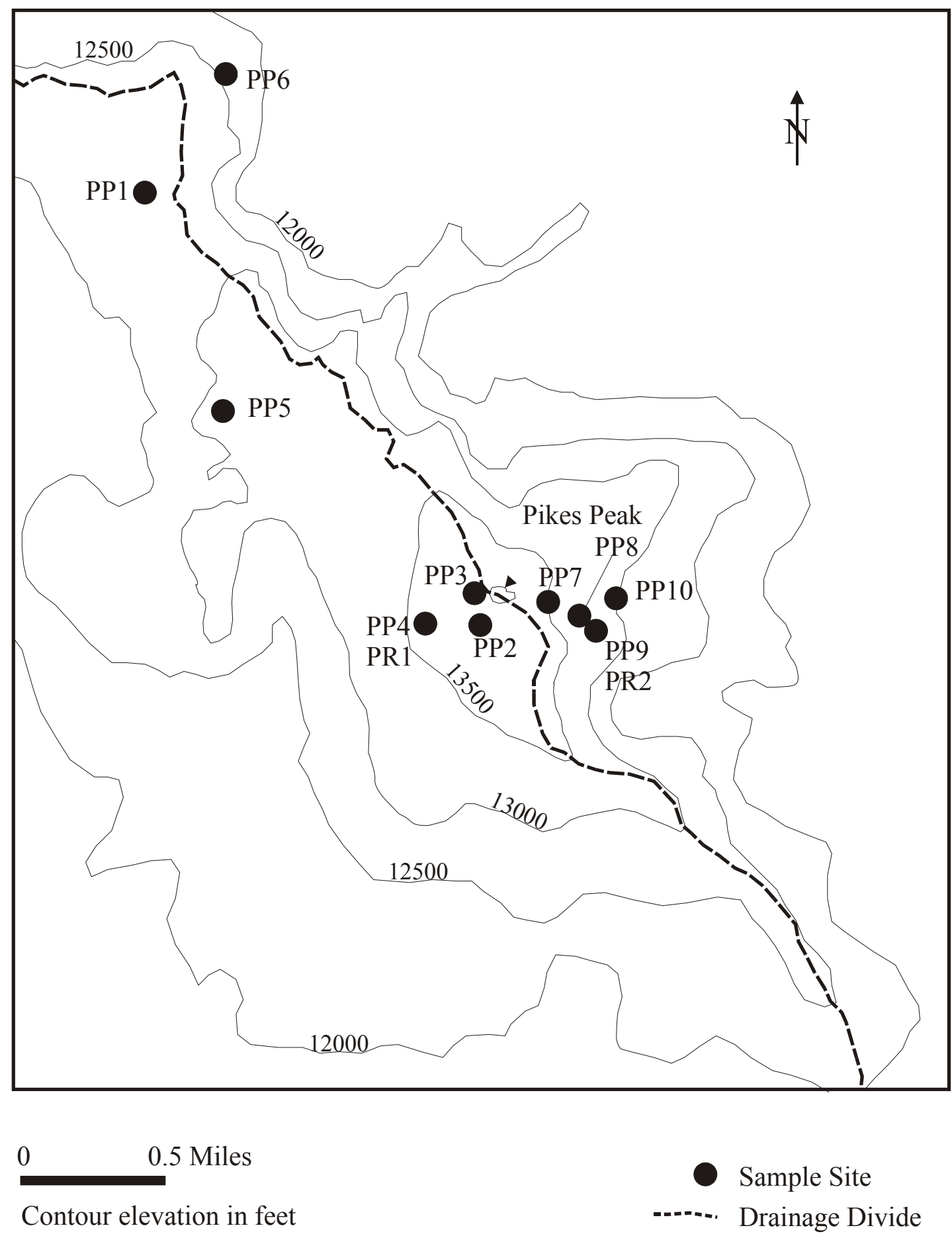

Figure 3. Map showing locations of soil and rock samples from Pikes Peak study area 
type granite consisting of a potassic and a sodic series members. Within the study area the rocks consist of the potassic series Pikes Peak granite, which is a coarse-grained biotite +- hornblende, syenogranite and a potassic series Windy Peak granite, a finegrained to medium grained biotite granite, which is late-stage intrusion into the main Pikes Peak granite (Smith and others, 1999). For purposes of this study, the chemical composition of both rock types is nearly identical (see appendix 1). The soils are developed in place and not transported. They are derived from weathering of the underlying rock and are dark brown to brown in color. Some samples contain organic material (see comments in appendix 2). Soils are thin lithosols only present in some place, usually where the slope becomes less steep. Thickness ranges from 0 to around 6 inches. Where soils are absent, rock glaciers are usually present.

\section{Climate}

The study areas are located in the middle latitudes where the winds aloft are dominated by westerly airflow called the prevailing westerlies, but local surface winds can be highly variable. The study areas are dominated by highland continental climate. Daily weather depends on the temperature and moisture content of the air masses that pass overhead. Air masses are classified according to their origin and moisture content. Three maritime source areas and two continental source areas influence the climate of the two study areas and the Southern Rocky Mountains in general (Benedict, 1991). The maritime air masses develop over an ocean and are characterized by high water vapor content. Source areas for the study areas are: 1) maritime polar which consists of cool Pacific air from the northwest; 2) maritime tropical which consists of air from the Baja area of southern California; and 3) maritime tropical which consists of airflow from the Gulf of Mexico. The continental air masses develop over dry interior of a continent and are characterized by low water vapor content. Source areas are: 1) continental tropical from Mexico; and polar continental which consists of airflow from south-central Canada (Benedict, 1991). Therefore storms and wind can track from multiple directions over the study areas.

\section{Methods}

\section{Sample Collection}

Samples in the Hayden Pass study area were collected 8/5/02 and consist of three soils and two rocks on the west side of the range and two soils from the east side of the Sangre de Cristo Range (fig. 2). Samples in the Pikes Peak study area consist of five soils and one rock from both the west and east sides of Pikes Peak (fig. 3). Sites for soil samples were selected near the top of the ridge or peak on each side and then at lower elevations on each site. All the soil samples were developed in place on similar rocks. Soils were collected from beneath the surface to about four inches in depth. The soils are all poorly developed lithosols and range in depth from 0 to around 4 inches, although some pockets with transported soils are greater in depth. In the Hayden Pass area, the soils were sivied through a $<2 \mathrm{~mm}$ stainless steel mesh before collection. In the Pikes Peak area, higher moisture content precluded sieving and the soils were collected in bulk. All soil samples were composited from 4-6 sites. Rock samples were collected by compositing 4-6 rock chips from surface outcrops. 


\section{Sample Preparation}

In the laboratory soil samples were dried in a convection oven at ambient temperature and split using a Jones splitter. A split was then sieved using a 63 micron stainless steel sieve and the material passing through the sieve was used for all chemical analysis. This $<63$ micron fraction makes up the majority of the soil sample material. Rock samples were put through a jaw crusher and then ground to less than 100 mesh (150 micron) using a ceramic plate grinder.

\section{Analytical Methodology}

Total Elemental Composition: the total element composition for rock and soil samples was determined for 56 elements by inductively coupled plasma-mass spectrometry (ICPMS) after a multi-acid (hydrochloric, hydrofluoric, nitric, and perchloric) decomposition (Briggs and Meier, 1999). The elements determined, lower limits of determination, analytical results for rock and soil samples and duplicate samples are shown in appendix 1 and 2. Sample duplicates indicate good precision for the analysis.

$\mathbf{M g C l}_{\mathbf{2}}$ extraction: a $0.50 \mathrm{~g}$ soil sample was mixed with $10 \mathrm{ml}$ of $1 \mathrm{M} \mathrm{MgCl}_{2}$ (adjusted to $\mathrm{pH} 7$ with $\mathrm{NaOH}$ ) in a $20 \mathrm{ml}$ polypropylene centrifuge tube and placed on a reciprocating shaker set at 130 strokes per minute. After shaking for 30 minutes at room temperature the solid and solution were separated by centrifuging at $15,000 \mathrm{rpm}$ for 10 minutes in a refrigerated centrifuge set at 22 degrees $C$. One drop of concentrated nitric acid was then added to the solution for preservation purposes. The solution was then diluted 1:10 with $1 \% \mathrm{v} / \mathrm{v}$ nitric acid prior to determination of 30 selected elements by ICP-MS using matrix matching (modification of Briggs and Meier, 1999). The expected phase dissolution for this extraction is the water soluble, sorbed, and exchangeable fraction which contains the more mobile elements. Tessier and others (1979) discuss the use of magnesium chloride as an extracting reagent. The elements determined, lower limits of determination, and analytical results for the soil sample extracts are in appendix 3. Duplicate analysis of two soil samples indicates good precision for the analysis (appendix 3).

\section{Data}

\section{Hayden Pass Study Area}

Soil samples were collected along a traverse that crossed Hayden Pass in the Sangre de Cristo Range (fig. 2). Two soil samples from the east side and three soil samples from the west side were collected between elevations 10,380 to 10,750 feet (fig. 2). A cartoon of elevation change along the traverse is shown on fig. 4 . The results of the total elemental composition of the $<63$ micron fraction of the soils are shown in appendix 2. Selected elements, means on each side of the pass and percent difference of means of the two sides are shown in table 1 . For both study areas the percent difference was calculated by:

Percent Difference $=(($ highest mean-other mean $) /$ highest mean $) \times 100$.

We considered significant differences to exist between the elemental means of the east and west sides of the two study areas if the difference in means of the two sides was greater than $20 \%$. Because the precision of analysis is less certain the closer to the detection limit of the analytical technique, the percent difference of elements whose 


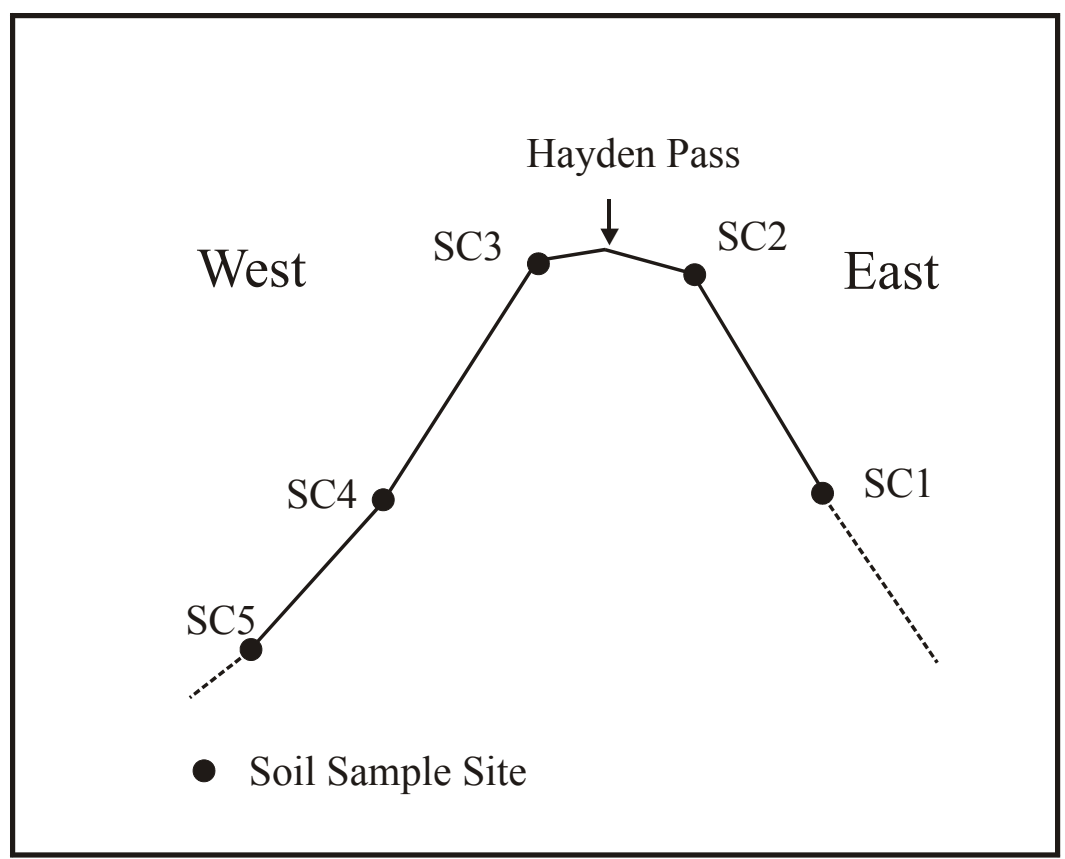

Figure 4. Cartoon showing location of soil samples from the Hayden Pass study area. Vertical height is exaggerated. 
Table 1. Selected elements of soils from the Hayden Pass and Pikes Peak study areas. A negative sign was added to the difference if the mean element content is higher on the west side relative to the east side and a positve value the opposite.

\begin{tabular}{|c|c|c|c|c|c|c|c|c|c|c|}
\hline Site & $\begin{array}{c}\mathrm{Ca} \\
\% \\
\end{array}$ & $\begin{array}{c}\mathrm{Mg} \\
\% \\
\end{array}$ & $\begin{array}{c}\mathrm{Na} \\
\%\end{array}$ & $\begin{array}{l}\mathrm{K} \\
\% \\
\end{array}$ & $\begin{array}{l}\mathrm{Al} \\
\% \\
\end{array}$ & $\begin{array}{l}\mathrm{Fe} \\
\% \\
\end{array}$ & $\begin{array}{l}\mathrm{P} \\
\% \\
\end{array}$ & $\begin{array}{l}\text { Ti \% } \\
\% \\
\end{array}$ & $\begin{array}{c}\mathrm{Mn} \\
\mathrm{ppm}\end{array}$ & $\begin{array}{c}\mathrm{Ag} \\
\mathrm{ppm}\end{array}$ \\
\hline $10 \times$ Limits $^{\top}$ & 0.5 & 0.1 & 0.1 & 0.1 & 0.1 & 0.1 & 0.1 & 0.1 & 3 & 0.2 \\
\hline \multicolumn{11}{|c|}{ Hayden Pass } \\
\hline \multicolumn{11}{|c|}{ West Side } \\
\hline SSC3 & 0.50 & 0.40 & 0.89 & 2.2 & 7.1 & 2.6 & 0.03 & 0.4 & 460 & 0.09 \\
\hline SSC4 & 0.61 & 0.46 & 1.0 & 1.8 & 6.5 & 2.2 & 0.04 & 0.4 & 630 & 0.07 \\
\hline SSC5 & 0.78 & 0.56 & 0.95 & 2.1 & 7.5 & 2.8 & 0.08 & 0.4 & 1500 & 0.08 \\
\hline Mean & 0.62 & 0.47 & 0.95 & 2.0 & 7.0 & 2.5 & 0.05 & 0.4 & 758 & 0.08 \\
\hline \multicolumn{11}{|c|}{ East Side } \\
\hline SSC2 & 0.50 & 0.45 & 1.0 & 1.9 & 7.2 & 2.4 & 0.05 & 0.5 & 610 & 0.11 \\
\hline SSC1 & 0.40 & 0.26 & 0.70 & 1.4 & 4.8 & 1.5 & 0.02 & 0.4 & 160 & 0.12 \\
\hline Mean & 0.45 & 0.34 & 0.8 & 1.6 & 5.9 & 1.9 & 0.03 & 0.4 & 312 & 0.11 \\
\hline Difference $^{2}$ & 27.8 & 27.0 & 11.5 & 19.5 & 16.3 & 24.7 & n.d. ${ }^{3}$ & 0.0 & 58.8 & n.d. \\
\hline \multicolumn{11}{|c|}{ Pikes Peak } \\
\hline \multicolumn{11}{|c|}{ West Side } \\
\hline PPS3 & 0.52 & 0.61 & 1.6 & 2.9 & 7.9 & 3.5 & 0.18 & 0.4 & 1400 & 0.18 \\
\hline PPS2 & 0.84 & 0.32 & 2.6 & 3.9 & 8.5 & 3.8 & 0.11 & 0.5 & 950 & 0.49 \\
\hline PPS4 & 0.60 & 0.54 & 2.0 & 3.5 & 8.6 & 3.4 & 0.14 & 0.4 & 730 & 0.32 \\
\hline PPS5 & 0.50 & 0.43 & 2.0 & 3.4 & 8.3 & 3.9 & 0.12 & 0.4 & 740 & 0.47 \\
\hline PPS1 & 0.51 & 0.38 & 2.0 & 2.9 & 7.2 & 2.8 & 0.10 & 0.3 & 520 & 0.46 \\
\hline Mean & 0.58 & 0.44 & 2.0 & 3.3 & 8.1 & 3.5 & 0.13 & 0.4 & 821 & 0.36 \\
\hline \multicolumn{11}{|c|}{ East Side } \\
\hline PPS7 & 0.58 & 0.52 & 1.8 & 3.0 & 7.9 & 3.5 & 0.12 & 0.4 & 720 & 0.46 \\
\hline PPS8 & 0.66 & 0.65 & 1.3 & 2.5 & 8.1 & 3.8 & 0.20 & 0.3 & 690 & 1.00 \\
\hline PPS9 & 0.50 & 0.74 & 1.2 & 2.6 & 8.6 & 4.1 & 0.19 & 0.3 & 1100 & 0.56 \\
\hline PPS10 & 0.5 & 0.53 & 1.1 & 2.2 & 6.8 & 2.9 & 0.17 & 0.3 & 420 & 0.26 \\
\hline PPS6 & 0.57 & 0.37 & 2.3 & 3.0 & 8.4 & 3.7 & 0.07 & 0.3 & 570 & 1.40 \\
\hline Mean & 0.56 & 0.55 & 1.5 & 2.6 & 7.9 & 3.6 & 0.14 & 0.3 & 666 & 0.62 \\
\hline Difference & 4.0 & -18.9 & 26.6 & 19.9 & 1.9 & -3.3 & -9.3 & 19.5 & 18.9 & -42.1 \\
\hline
\end{tabular}

\footnotetext{
${ }^{1} 10 \times$ detection limit; ${ }^{2}$ difference in percent $=(($ highest mean-other mean $) /$ highest $) \times 100 ;{ }^{3}$ not determined because means were less than $10 x$ the dection limit
} 
Table 1. Selected elements of soils from the Hayden Pass and Pikes Peak study areas. A negative sign was added to the difference if the mean element content is higher on the west side relative to the east side and a positve value the opposite.

\begin{tabular}{|c|c|c|c|c|c|c|c|c|c|c|c|c|}
\hline Site & $\begin{array}{c}\text { As } \\
\text { ppm }\end{array}$ & $\begin{array}{c}\mathrm{Ba} \\
\mathrm{ppm}\end{array}$ & $\begin{array}{c}\mathrm{Be} \\
\mathrm{ppm}\end{array}$ & $\begin{array}{c}\mathrm{Bi} \\
\mathrm{ppm}\end{array}$ & $\begin{array}{c}\mathrm{Cd} \\
\mathrm{ppm}\end{array}$ & $\begin{array}{c}\mathrm{Ce} \\
\mathrm{ppm}\end{array}$ & $\begin{array}{c}\text { Co } \\
\text { ppm }\end{array}$ & $\begin{array}{c}\mathrm{Cr} \\
\mathrm{ppm}\end{array}$ & $\begin{array}{c}\text { Cs } \\
\text { ppm }\end{array}$ & $\begin{array}{c}\mathrm{Cu} \\
\mathrm{ppm}\end{array}$ & $\begin{array}{c}\mathrm{La} \\
\mathrm{ppm}\end{array}$ & $\begin{array}{c}\mathrm{Li} \\
\mathrm{ppm}\end{array}$ \\
\hline $10 \mathrm{x}$ Limits $^{\top}$ & 5 & 20 & 1 & 0.7 & 1 & 1 & 1 & 10 & 1 & 30 & 1 & 5 \\
\hline \multicolumn{13}{|c|}{ Hayden Pass } \\
\hline \multicolumn{13}{|c|}{ West Side } \\
\hline SSC3 & 4.0 & 630 & 1.7 & 0.27 & 0.2 & 74 & 8.4 & 49 & 3.6 & 20 & 36 & 30 \\
\hline SSC4 & 5.4 & 700 & 1.4 & 0.32 & 0.3 & 58 & 9.6 & 45 & 4.0 & 20 & 32 & 33 \\
\hline SSC5 & 6.9 & 700 & 2.1 & 0.41 & 1.0 & 82 & 14 & 51 & 4.7 & 30 & 40 & 42 \\
\hline Mean & 5.3 & 676 & 1.7 & 0.33 & 0.4 & 71 & 10.4 & 48 & 4.1 & 23 & 36 & 35 \\
\hline \multicolumn{13}{|c|}{ East Side } \\
\hline SSC2 & 4.0 & 690 & 1.2 & 0.35 & 0.2 & 73 & 7.2 & 52 & 4.1 & 20 & 36 & 32 \\
\hline SSC1 & 3.0 & 480 & 1.0 & 0.40 & $<0.1$ & 37 & 3.3 & 46 & 2.6 & 9 & 21 & 17 \\
\hline Mean & 3.5 & 575 & 1.1 & 0.37 & 0.2 & 52 & 4.9 & 49 & 3.3 & 13 & 27 & 23 \\
\hline Difference $^{2}$ & n.d. & 14.8 & 35.9 & n.d. & n.d. & 26.4 & 53.2 & -1.3 & 19.9 & n.d. & -11.6 & -21.2 \\
\hline \multicolumn{13}{|c|}{ Pikes Peak } \\
\hline \multicolumn{13}{|c|}{ West Side } \\
\hline PPS3 & 4.0 & 610 & 6.8 & 0.87 & 0.2 & 340 & 8.3 & 32 & 5.5 & 30 & 180 & 42 \\
\hline PPS2 & $<0.5$ & 670 & 7.8 & 0.10 & 0.2 & 600 & 3.9 & 10 & 3.5 & 8 & 310 & 42 \\
\hline PPS4 & 4.0 & 600 & 6.9 & 0.40 & 0.4 & 430 & 5.7 & 26 & 6.1 & 20 & 220 & 53 \\
\hline PPS5 & 2.0 & 540 & 8.3 & 0.32 & 0.4 & 550 & 4.2 & 23 & 5.4 & 10 & 280 & 55 \\
\hline PPS1 & 5.0 & 490 & 5.8 & 0.38 & 0.6 & 300 & 3.8 & 25 & 5.1 & 10 & 160 & 52 \\
\hline Mean & 2.2 & 579 & 7.1 & 0.34 & 0.3 & 429 & 4.9 & 22 & 5.0 & 14 & 223 & 48 \\
\hline \multicolumn{13}{|c|}{ East Side } \\
\hline PPS7 & 6.7 & 630 & 8.2 & 0.77 & 0.9 & 570 & 6.4 & 31 & 5.1 & 20 & 300 & 64 \\
\hline PPS8 & 11.0 & 560 & 6.0 & 0.68 & 0.8 & 380 & 7.0 & 38 & 7.0 & 30 & 210 & 65 \\
\hline PPS9 & 7.9 & 540 & 6.2 & 0.72 & 0.6 & 280 & 7.8 & 36 & 8.0 & 20 & 160 & 66 \\
\hline PPS10 & 5.9 & 480 & 4.9 & 0.44 & 0.7 & 260 & 4.9 & 31 & 5.5 & 20 & 140 & 47 \\
\hline PPS6 & 4.0 & 330 & 9.2 & 0.27 & 0.6 & 840 & 3.3 & 19 & 4.6 & 10 & 400 & 89 \\
\hline Mean & 6.7 & 497 & 6.7 & 0.54 & 0.7 & 421 & 5.6 & 30 & 5.9 & 19 & 224 & 65 \\
\hline Difference & -67.7 & 16.5 & 4.8 & n.d. & n.d. & 1.8 & -12.2 & -28.1 & -14.9 & n.d. & -0.5 & -25.3 \\
\hline
\end{tabular}

\footnotetext{
${ }^{1} 10 \times$ detection limit; ${ }^{2}$ difference in percent $=(($ highest mean-other mean $) /$ highest $) \times 100 ;{ }^{3}$ not determined because means were less than $10 x$ the dection limit
} 
Table 1. Selected elements of soils from the Hayden Pass and Pikes Peak study areas. A negative sign was added to the difference if the mean element content is higher on the west side relative to the east side and a positve value the opposite.

\begin{tabular}{|c|c|c|c|c|c|c|c|c|c|c|c|c|c|}
\hline Site & $\begin{array}{c}\text { Mo } \\
\text { ppm }\end{array}$ & $\begin{array}{c}\mathrm{Ni} \\
\mathrm{ppm}\end{array}$ & $\begin{array}{c}\mathrm{Pb} \\
\mathrm{ppm}\end{array}$ & $\begin{array}{c}\mathrm{Rb} \\
\mathrm{ppm}\end{array}$ & $\begin{array}{c}\mathrm{Sb} \\
\mathrm{ppm}\end{array}$ & $\begin{array}{c}\text { Sn } \\
\mathrm{ppm}\end{array}$ & $\begin{array}{c}\mathrm{Sr} \\
\mathrm{ppm}\end{array}$ & $\begin{array}{c}\text { Th } \\
\mathrm{ppm}\end{array}$ & $\begin{array}{c}\mathrm{U} \\
\mathrm{ppm}\end{array}$ & $\begin{array}{c}\mathrm{V} \\
\mathrm{ppm}\end{array}$ & $\begin{array}{c}\text { W } \\
\mathrm{ppm}\end{array}$ & $\begin{array}{c}\mathrm{Y} \\
\mathrm{ppm}\end{array}$ & $\begin{array}{c}\mathrm{Zn} \\
\mathrm{ppm}\end{array}$ \\
\hline $10 \mathrm{x}$ Limits $^{\top}$ & 1 & 1 & 1 & 1 & 1 & 10 & 3 & 0.5 & 0.5 & 10 & 1 & 1 & 30 \\
\hline \multicolumn{14}{|c|}{ "Hayden Pass } \\
\hline \multicolumn{14}{|c|}{ West Side } \\
\hline SSC3 & 1.1 & 16.0 & 26 & 90 & 0.4 & 2 & 120 & 11 & 3.9 & 67 & 1.4 & 17 & 48 \\
\hline SSC4 & 1.2 & 14.0 & 37 & 84 & 0.5 & 2 & 150 & 9 & 2.9 & 61 & 1.1 & 16 & 69 \\
\hline SSC5 & 1.4 & 21.0 & 50 & 91 & 0.6 & 2 & 150 & 11 & 3.7 & 70 & 1.8 & 24 & 120 \\
\hline Mean & 1.2 & 16.8 & 36 & 88 & 0.5 & 2 & 139 & 10 & 3.5 & 66 & 1.4 & 19 & 74 \\
\hline \multicolumn{14}{|c|}{ East Side } \\
\hline SSC2 & 1.4 & 14.0 & 23 & 94 & 0.6 & 2 & 140 & 11 & 3.6 & 72 & 2.1 & 16 & 69 \\
\hline SSC1 & 1.3 & 8.7 & 15 & 66 & 0.4 & 2 & 93 & 7 & 2.4 & 60 & 1.5 & 11 & 20 \\
\hline Mean & 1.3 & 11.0 & 19 & 79 & 0.5 & 2 & 114 & 9 & 2.9 & 66 & 1.8 & 13 & 37 \\
\hline Difference $^{2}$ & -9.0 & -25.3 & -37.5 & -3.1 & n.d. & n.d. & -7.7 & -7.7 & 15.3 & 0 & -26.3 & 29.0 & 49.5 \\
\hline \multicolumn{14}{|c|}{ Pikes Peak } \\
\hline \multicolumn{14}{|c|}{ West Side } \\
\hline PPS3 & 3.4 & 11.0 & 56 & 170 & 0.6 & 17 & 120 & 51 & 14 & 60 & 3.5 & 110 & 160 \\
\hline PPS2 & 2.7 & 4.7 & 50 & 210 & 0.2 & 12 & 110 & 65 & 12 & 27 & 5.1 & 220 & 140 \\
\hline PPS4 & 2.9 & 8.9 & 66 & 210 & 0.5 & 12 & 110 & 59 & 12 & 44 & 5.2 & 140 & 140 \\
\hline PPS5 & 4.5 & 7.5 & 57 & 220 & 0.5 & 10 & 92 & 62 & 9.8 & 38 & 4.9 & 150 & 160 \\
\hline PPS1 & 2.7 & 7.6 & 59 & 220 & 0.6 & 11 & 100 & 46 & 10 & 38 & 4.2 & 120 & 130 \\
\hline Mean & 3.2 & 7.7 & 57 & 205 & 0.4 & 12 & 106 & 56 & 11 & 40 & 4.5 & 144 & 146 \\
\hline \multicolumn{14}{|c|}{ East Side } \\
\hline PPS7 & 3.5 & 10 & 150 & 190 & 1.0 & 16 & 120 & 94 & 18 & 50 & 4.8 & 220 & 200 \\
\hline PPS8 & 4.6 & 13 & 110 & 170 & 1.5 & 16 & 120 & 61 & 16 & 54 & 4.4 & 250 & 200 \\
\hline PPS9 & 5.6 & 13 & 68 & 180 & 1.0 & 12 & 99 & 44 & 16 & 60 & 4.6 & 160 & 210 \\
\hline PPS10 & 3.6 & 11 & 50 & 140 & 1.0 & 6.8 & 98 & 45 & 9.7 & 49 & 2.8 & 81 & 130 \\
\hline PPS6 & 4.1 & 6.6 & 84 & 240 & 0.5 & 22 & 75 & 140 & 29 & 28 & 8.2 & 420 & 150 \\
\hline Mean & 4.2 & 10.4 & 86 & 181 & 0.9 & 14 & 101 & 69 & 17 & 47 & 4.7 & 197 & 175 \\
\hline Difference & -24.6 & -26.6 & -33.3 & 11.6 & n.d. & -10.1 & 4.7 & -18.9 & -31.4 & -14.3 & -3.1 & -27.3 & -16.8 \\
\hline
\end{tabular}

\footnotetext{
${ }^{1} 10 \times$ detection limit; ${ }^{2}$ difference in percent $=(($ highest mean-other mean $) /$ highest $) \times 100 ;{ }^{3}$ not determined because means were less than $10 x$ the dection limit
} 
values were less than 10 times the detection limit were not calculated. Significant differences in elemental means of the east and west side of Hayden Pass are shown in bold on table 1. Negative sign for percent difference was added to indicates that the mean element content is higher on the west side relative to the east side and a positive sign the opposite. The ranking of significant differences in elemental means on the west side that are elevated relative to the east side is $\mathrm{Mn}>\mathrm{Co}>\mathrm{Zn}>\mathrm{Be}>\mathrm{Y}>\mathrm{Ca}>\mathrm{Mg}>$ $\mathrm{Ce}>\mathrm{Fe}$. This means that these elements are concentrated on the west side relative to the east side. The ranking of significant differences in elemental means that are elevated on the east side relative to the west side is $\mathrm{Pb}>\mathrm{W}>\mathrm{Ni}>\mathrm{Li}$. The Minturn Formation consisting of medium to coarse sandstone underlies the study area (Taylor and others, 1975). Two rock samples were collected to look at local variation in the rock chemistry (appendix 1). Some of the elements vary within the study area but not enough samples were collected to see systematic local variation. Some elements such as P, As, and Cd show little or no local variation and others such as $\mathrm{Ni}$ and Li have considerable variation. For the purposes of this preliminary investigation, the assumption is made that mean elemental differences between the east and west side for most elements probably reflect the input of elements in aerosols and dust contained in the winds aloft.

In order to investigate the more mobile elements present in the soils of the study area, extractions of soils were carried out using $\mathrm{MgCl}_{2}$. The $\mathrm{MgCl}_{2}$ extraction technique targets the water soluble, sorbed, and exchangeable fraction of the soils (Tessier, 1979). In addition, the extractions of the mobile elements should reduce the effect of the local variation in rock geochemistry. The chemical analyses of the extracts are shown in appendix 3. Selected elements, means of the east and west sides of the study area, and significant mean differences between the east and west sides are shown in table 2. Ca is the only element that is elevated on the west side relative to the east side.

The rankings of significant differences of elevated elements on the east side relative to the west side is $\mathrm{Al}>\mathrm{Pb}>\mathrm{Sr}>\mathrm{Rb}>\mathrm{Mn}>\mathrm{Co}$.

\section{Pikes Peak Study Area}

Soil samples were collected on the east and west sides of Pikes Peak in the Front Range (fig. 3). The study area lies approximately 12 miles west of Colorado Springs. Five soil samples were collected from both the west and east side of Pikes Peak between elevations 12,440 to 14,070 feet on $9 / 17$ to $9 / 18 / 02$. A cartoon of elevation change along the traverse is shown on fig. 5. The results of the chemical analyses of the $<63$ micron fraction of the soils are shown in appendix 2. Selected elements, elemental means on each side of the pass and differences in elemental means of the two sides are shown in table 1. Significant difference was calculated similarly to soils from the Hayden Pass study area. Significant differences in elemental means of the east and west side of Pikes Peak is shown in bold on table 1. Negative value for percent difference indicates that the mean element content is higher on the west side relative to the east side and a positive sign the opposite. The Pikes Peak and Windy Peak Granites underlies the study area (Wobus and others, 1976). Two rock samples were collected to look at local variation in the rock chemistry (appendix 1). The local variations of the rocks in the Pikes Peak study area are less than in the Hayden Pass study area. For the purposes of this preliminary investigation, the assumption is made that mean elemental differences in the east and 


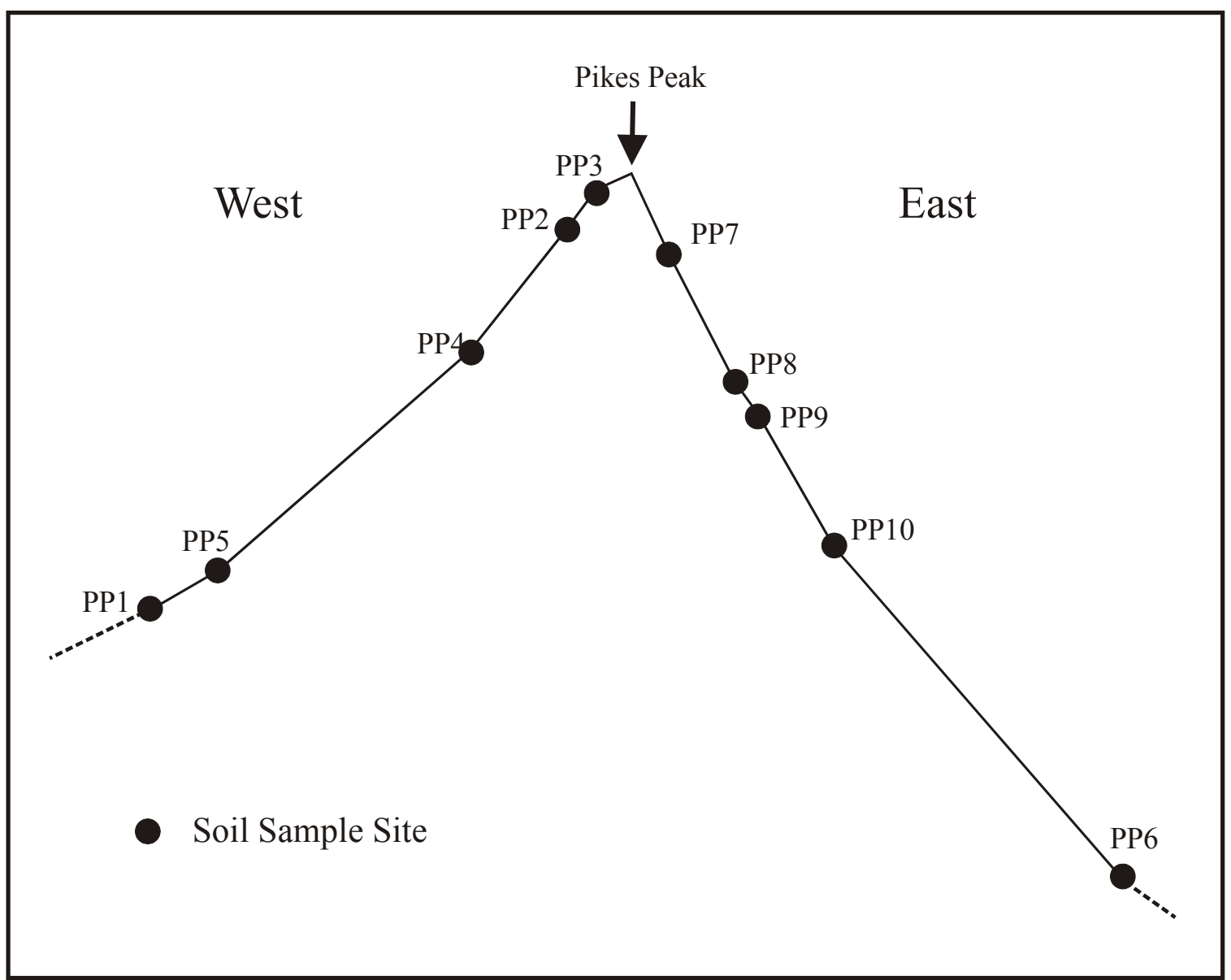

Figure 5. Cartoon showing location of soil samples for Pikes Peak study area. Vertical height is exaggerated. 
Table 2. Selected elements of a $\mathrm{MgCl}_{2}$ extract os of soils from the Hayden Pass and Pikes Peak study area. A negative sign was added to the difference if the mean element content is higher on the west side relative to the east side and a positive value the opposite.

\begin{tabular}{|c|c|c|c|c|c|c|c|c|c|c|c|}
\hline Site & $\mathrm{Ca}$ & $\mathrm{Na}$ & $\mathrm{K}$ & $\mathrm{Al}$ & $\mathrm{Fe}$ & $\mathrm{Mn}$ & As & $\mathrm{Ba}$ & $\mathrm{Be}$ & $\mathrm{Cd}$ & $\mathrm{Co}$ \\
\hline $10 \times$ Limit $^{1}$ & 400 & 200 & 60 & 4 & 100 & 0.4 & 2 & 0.4 & 0.4 & 0.4 & 0.4 \\
\hline \multicolumn{12}{|c|}{ "Hayden Pass } \\
\hline \multicolumn{12}{|c|}{ West Side } \\
\hline SSC3 & 840 & $<20$ & 80.9 & 18.9 & $<10$ & 26.6 & $<0.2$ & 27.5 & 0.01 & 0.11 & 0.74 \\
\hline SSC4 & 620 & $<20$ & 60.3 & 61.8 & $<10$ & 28.4 & $<0.2$ & 33.8 & $<0.01$ & 0.11 & 0.62 \\
\hline SSC5 & 2320 & $<20$ & 255 & 15.1 & $<10$ & 22.4 & $<0.2$ & 44.4 & $<0.01$ & 0.44 & 0.48 \\
\hline Mean & 1065 & $<20$ & 108 & 26.0 & $<10$ & 25.7 & $<0.2$ & 34.6 & $<0.01$ & 0.17 & 0.60 \\
\hline \multicolumn{12}{|c|}{ East Side } \\
\hline SSC2 & 483 & $<20$ & 62.7 & 234 & 12 & 68.7 & $<0.2$ & 39.3 & 0.03 & 0.10 & 0.92 \\
\hline SSC1 & 987 & $<20$ & 37.1 & 201 & 22 & 21.4 & 0.4 & 36.2 & 0.02 & 0.05 & 0.74 \\
\hline Mean & 690 & $<20$ & 48.2 & 217 & 16 & 38.3 & 0.2 & 37.7 & 0.02 & 0.07 & 0.83 \\
\hline Difference $^{2}$ & 35.2 & n.d. ${ }^{3}$ & n.d. & -88.0 & n.d. & -33.0 & nd & -8.4 & nd & n.d. & -26.8 \\
\hline \multicolumn{12}{|c|}{ Pikes Peak } \\
\hline \multicolumn{12}{|c|}{ West Side } \\
\hline PPS3 & 535 & $<20$ & 52.9 & 302 & $<10$ & 7.3 & 0.7 & 11.8 & 0.05 & 0.06 & 0.70 \\
\hline PPS2 & 1230 & $<20$ & 52.8 & 2.30 & $<10$ & 4.3 & $<0.2$ & 33.0 & $<0.01$ & 0.07 & 1.15 \\
\hline PPS4 & 728 & $<20$ & 34.0 & 32.1 & $<10$ & 1.3 & $<0.2$ & 9.06 & 0.02 & 0.10 & 0.75 \\
\hline PPS5 & 828 & $<20$ & 58.9 & 116 & $<10$ & 4.1 & $<0.2$ & 16.3 & 0.04 & 0.20 & 0.60 \\
\hline PPS1 & 673 & $<20$ & 61.8 & 102 & $<10$ & 6.2 & $<0.2$ & 18.0 & 0.02 & 0.22 & 0.47 \\
\hline Mean & 768 & $<20$ & 51.0 & 48 & $<10$ & 4.0 & $<0.2$ & 16.0 & 0.02 & 0.11 & 0.70 \\
\hline \multicolumn{12}{|c|}{ East Side } \\
\hline PPS7 & 963 & 95.2 & 53.1 & 71.1 & $<10$ & 17.4 & $<0.2$ & 36.0 & 0.01 & 0.45 & 0.80 \\
\hline PPS8 & 2790 & 35.0 & 63.6 & 134 & $<10$ & 9.5 & $<0.2$ & 53.2 & 0.04 & 0.48 & 0.90 \\
\hline PPS9 & 1780 & 15 & 271 & 333 & $<10$ & 37.7 & $<0.2$ & 40.3 & 0.1 & 0.39 & 0.96 \\
\hline PPS10 & 1610 & 37.9 & 326 & 194 & $<10$ & 24.8 & $<0.2$ & 31.6 & 0.05 & 0.52 & 1.32 \\
\hline PPS6 & 2430 & 15 & 111 & 43.5 & $<10$ & 8.0 & $<0.2$ & 21.5 & 0.02 & 0.40 & 0.93 \\
\hline Mean & 1796 & 31 & 127 & 122 & $<10$ & 16.5 & $<0.2$ & 35.0 & 0.03 & 0.45 & 0.97 \\
\hline Difference & -57.3 & n.d. & n.d. & -60.3 & nd & -75.7 & nd & -54.4 & n.d. & n.d. & -27.5 \\
\hline
\end{tabular}

${ }^{1} 10 \times$ detection limit; ${ }^{2}$ difference in percent $=(($ highest mean-other mean $) /$ highest mean $) \times 100 ;{ }^{3}$ not determined because means were less than $10 \mathrm{x}$ deterction limit. 
Table 2. Selected elements of a $\mathrm{MgCl}_{2}$ extract os of soils from the Hayden Pass and Pikes Peak study area. A negative sign was added to the difference if the mean element content is higher on the west side relative to the east side and a positive value the opposite.

\begin{tabular}{|c|c|c|c|c|c|c|c|}
\hline $\mathrm{Cr}$ & $\mathrm{Cu}$ & $\mathrm{Ni}$ & $\mathrm{Pb}$ & $\mathrm{Rb}$ & $\mathrm{Sb}$ & $\mathrm{Sr}$ & $\mathrm{Zn}$ \\
\hline 2 & 1 & 0.8 & 0.1 & 0.02 & 0.6 & 1.0 & 1 \\
\hline \multicolumn{8}{|c|}{ Hayden Pass } \\
\hline$<0.2$ & $<0.1$ & 0.8 & 1.4 & 0.15 & 0.27 & 5.7 & 0.3 \\
\hline$<0.2$ & $<0.1$ & 0.6 & 2.0 & 0.18 & 0.22 & 3.9 & 0.3 \\
\hline$<0.2$ & $<0.1$ & 0.8 & $<0.01$ & 0.19 & 0.20 & 14.5 & 2.9 \\
\hline$<0.2$ & $<0.1$ & 0.7 & 0.3 & 0.17 & 0.23 & 6.9 & 0.6 \\
\hline \multicolumn{8}{|c|}{ East Side } \\
\hline 0.15 & $<0.1$ & 0.8 & 1.6 & 0.12 & 0.35 & 3.4 & 2.4 \\
\hline 0.2 & 0.4 & 0.8 & 2.3 & 0.10 & 0.51 & 5.1 & 1.0 \\
\hline$<0.2$ & 0.2 & 0.8 & 1.9 & 0.11 & 0.42 & 4.2 & 1.5 \\
\hline n.d. & n.d. & n.d. & -85.9 & 36.5 & n.d. & 39.3 & n.d. \\
\hline
\end{tabular}

Pikes Peak

\begin{tabular}{cccccccc}
\multicolumn{7}{c}{ Pikes Peak } \\
\hline \multicolumn{7}{c}{ West Side } \\
0.2 & $<0.1$ & 0.6 & 2.3 & 0.26 & 0.1 & 2.5 & 1 \\
0.3 & $<0.1$ & 1.2 & $<0.01$ & 0.11 & 0.1 & 6.7 & 1 \\
0.2 & $<0.1$ & 0.7 & 2.2 & 0.23 & 0.09 & 3.1 & $<0.1$ \\
0.2 & $<0.1$ & 0.6 & 3.1 & 0.39 & 0.07 & 4.1 & 0.5 \\
$<0.2$ & $<0.1$ & 0.5 & 4.4 & 0.39 & 0.2 & 3.7 & 2 \\
0.20 & $<0.1$ & 0.7 & 0.9 & 0.25 & 0.1 & 3.8 & 0.6 \\
& & & & & & & \\
\hline 0.3 & $<0.1$ & 0.8 & 28.2 & 0.38 & 0.09 & 7.4 & 6.2 \\
0.3 & $<0.1$ & 1.1 & 17.0 & 0.68 & 0.09 & 29.2 & 4.5 \\
0.3 & $<0.1$ & 1.2 & 7.1 & 0.54 & 0.07 & 11.8 & 4.6 \\
0.5 & $<0.1$ & 1.4 & 6.2 & 0.30 & $<0.06$ & 9.9 & 4.8 \\
0.2 & $<0.1$ & 1.0 & 3.6 & 0.69 & 0.07 & 11.5 & 2.4 \\
0.3 & $<0.1$ & 1.1 & 9.5 & 0.49 & 0.07 & 12.4 & 4.3 \\
n.d. & n.d. & n.d. & -90.9 & -49.0 & nd & -69.1 & n.d. \\
\hline
\end{tabular}

${ }^{1} 10 \times$ detection limit; ${ }^{2}$ difference in percent $=(($ highest mean-other mean $) /$ highest mean $) \times 100 ;{ }^{3}$ not determined because means were less than $10 \mathrm{x}$ deterction limit. 
west side probably reflects the input of elements in aerosols and dust contained in the winds aloft.

Only $\mathrm{Na}$ is elevated on the west side relative to the east side (table 1). A large number of elements are concentrated on the east side relative to the west side. The ranking of significant differences in elemental means that are elevated on the east side relative to the west side is $\mathrm{Ag}>\mathrm{Pb}>\mathrm{U}>\mathrm{Cr}>\mathrm{Y}>\mathrm{Ni}>\mathrm{Li}>\mathrm{Mo}$.

In order to investigate the more mobile elements present in the soils of the study area, extractions of soils was carried out using $\mathrm{MgCl}_{2}$ similar to that carried out on the soils from Hayden Pass. The chemical analyses of the extracts are shown in appendix 3. Selected elements, elemental means of the east and west sides of the study area, and significant mean differences between the east and west sides are shown in table 2 . No elements are elevated on the west side relative to the east side. The rankings of significant differences of elevated elements on the east side relative to the west side is $\mathrm{Pb}$ $>\mathrm{Mn}>\mathrm{Sr}>\mathrm{Al}>\mathrm{Ca}>\mathrm{Rb}$. 


\section{References}

Benedict, A.D., 1991, The southern Rockies: San Francisco, Sierra Club Books, 578 p.

Briggs, P.H. and Meier, A.L., 1999, The determination of forty two elements in Geological materials by inductively coupled plasma-mass spectrometry: U.S. Geological Survey Open-File Report 99-166, 15 p.

Colorado Climate Center, 1984, Colorado average annual precipitation 1951-1980: Compiled by Climate Center, Department Atmospheric Science, Colorado State University, Fort Collins, scale1:500,000.

Lindsey, D.A., Clark, R.F., and Soulliere, S.J., 1985, Reference section for the Minturn Formation (Middle Pennsylvanian) Northern Sangre de Cristo Range, Custer County, Colorado: U.S. Geological Survey Miscellaneous Field Studies Map, MF 1622-C.

Marshall, B.D. and DePaolo, D.J., 1982, Precise age determinations and petrogenetic studies using the K-Ca method: Geochimica et Cosmochimica Acta, v. 46, p. 2537-2545.

Smith, D.R., Noblett, J., Wobus, R., Unruh, D., and Chamberlain, K.R., 1999, A review of the Pikes Peak batholith, Front Range, central Colorado: a "type example" of A-type granitic magmatism: Rocky Mountain Geology, v. 34, n. 2, p. 289-312.

Tayor, R., Scott, G.R., and Wobus, R.A., 1975, Reconnaissance geologic map of the Howard Quadrangle, central Colorado: U.S. Geological Survey Miscellaneous Investigations, I-892, scale 1:62,500.

Tessier, A., Campbell, P.G.C., and Bisson, M., 1979, Sequential extraction procedure for the speciation of particulate trace metals: Analytical Chemistry, v. 51, no. 7, p. 844-851.

Wobus, R.A., Epis, R.C., and Scott, G.R., 1976, Reconnaissance geologic map of the Cripple Creek-Pikes Peak area, Teller, Fremont, and El Paso Counties, Colorado: Colorado: U.S. Geological Survey Miscellaneous Field Studies Map, MF-805, scale 1:48,000. 
Appendix 1. Chemical analysis of rocks from the Hayden Pass and Pikes Peak study areas.

\begin{tabular}{ccccccc}
\hline Site & Comment & $\begin{array}{c}\text { Latitute } \\
\text { Degree }\end{array}$ & $\begin{array}{c}\text { Longitute } \\
\text { Degree }\end{array}$ & $\begin{array}{c}\text { Elevation } \\
\text { Ag } \\
\mathrm{ppm}\end{array}$ & $\begin{array}{c}\mathrm{Al} \\
\%\end{array}$ & $\begin{array}{c}\text { As } \\
\mathrm{ppm}\end{array}$ \\
\hline \hline & & & & & & \\
Detection Limit & & & $<0.02<0.01<0.5$ \\
\hline
\end{tabular}

Hayden Pass Area

\begin{tabular}{|c|c|c|c|c|c|c|c|}
\hline $\begin{array}{l}\text { RSC01 } \\
\text { RSC02 }\end{array}$ & $\begin{array}{l}\text { Minturn Formation } \\
\text { Minturn Formation }\end{array}$ & $\begin{array}{l}38.2922 \\
38.2931\end{array}$ & $\begin{array}{l}105.8494 \\
105.8547\end{array}$ & $\begin{array}{l}10720 \\
10380\end{array}$ & $\begin{array}{l}0.06 \\
0.04\end{array}$ & $\begin{array}{l}4.1 \\
2.6\end{array}$ & $\begin{array}{l}2 \\
2\end{array}$ \\
\hline \multicolumn{8}{|c|}{ Pikes Peak Area } \\
\hline PPR01 & Windy Peak Granite & 38.8385 & 105.0488 & 13680 & 0.12 & 7.8 & $<0.5$ \\
\hline PPR02 & Pikes Peak Granite & 38.8395 & 105.0397 & 13530 & 0.15 & 8.1 & $<0.5$ \\
\hline \multicolumn{8}{|c|}{ Duplicate } \\
\hline RSC01R & Duplicate & & & & 0.02 & 4.3 & 1 \\
\hline
\end{tabular}


Appendix 1. Chemical analysis of rocks from the Hayden Pass and Pikes Peak study areas.

\begin{tabular}{ccccccccccc}
\hline Site & $\begin{array}{c}\mathrm{Au} \\
\mathrm{ppm}\end{array}$ & $\begin{array}{c}\mathrm{Ba} \\
\mathrm{ppm}\end{array}$ & $\begin{array}{c}\mathrm{Be} \\
\mathrm{ppm}\end{array}$ & $\begin{array}{c}\mathrm{Bi} \\
\mathrm{ppm}\end{array}$ & $\begin{array}{c}\mathrm{Ca} \\
\%\end{array}$ & $\begin{array}{c}\mathrm{Cd} \\
\mathrm{ppm}\end{array}$ & $\begin{array}{c}\mathrm{Ce} \\
\mathrm{ppm}\end{array}$ & $\begin{array}{c}\mathrm{Co} \\
\mathrm{ppm}\end{array}$ & $\begin{array}{c}\mathrm{Cr} \\
\mathrm{ppm}\end{array}$ & $\begin{array}{c}\mathrm{Cs} \\
\mathrm{ppm}\end{array}$ \\
\hline \hline & & & & & & & & & & \\
Detection Limit & $<0.05$ & $<2$ & $<0.1$ & $<0.07$ & $<0.05$ & $<0.1$ & $<0.1$ & $<0.1$ & $<1$ & $<0.1$ \\
\hline
\end{tabular}

Hayden Pass Area

\begin{tabular}{|c|c|c|c|c|c|c|c|c|c|c|}
\hline RSC01 & $<0.05$ & 200 & 0.6 & $<0.07$ & 0.07 & $<0.1$ & 75 & 10 & 13 & 0.7 \\
\hline RSC02 & $<0.05$ & 110 & 0.5 & $<0.07$ & 0.07 & $<0.1$ & 12 & 6.0 & 6 & 0.5 \\
\hline & \multicolumn{10}{|c|}{ Pikes Peak Area } \\
\hline PPR01 & $<0.05$ & 440 & 6.6 & $<0.07$ & 0.4 & $<0.1$ & 290 & 0.7 & $<1$ & 2.5 \\
\hline \multirow[t]{2}{*}{ PPR02 } & $<0.05$ & 870 & 8.0 & $<0.07$ & 0.74 & $<0.1$ & 260 & 1.4 & $<1$ & 3.5 \\
\hline & \multicolumn{10}{|c|}{ Duplicate } \\
\hline RSC01R & $<0.05$ & 200 & 0.9 & $<0.07$ & 0.07 & $<0.1$ & 50 & 11 & 14 & 0.7 \\
\hline
\end{tabular}


Appendix 1. Chemical analysis of rocks from the Hayden Pass and Pikes Peak study areas.

\begin{tabular}{cccccccccc}
\hline Site & $\mathrm{Cu}$ & $\mathrm{Dy}$ & $\mathrm{Er}$ & $\mathrm{Eu}$ & $\mathrm{Fe}$ & $\mathrm{Ga}$ & $\mathrm{Gd}$ & $\mathrm{Ge}$ & $\mathrm{Ho}$ \\
& $\mathrm{ppm}$ & $\mathrm{ppm}$ & $\mathrm{ppm}$ & $\mathrm{ppm}$ & $\%$ & $\mathrm{ppm}$ & $\mathrm{ppm}$ & $\mathrm{ppm}$ & $\mathrm{ppm}$ \\
\hline \hline & & & & & & & & & \\
Detection Limit & $<3$ & $<0.005$ & $<0.005$ & $<0.005$ & $<0.01$ & $<0.1$ & $<0.005$ & $<0.1$ & $<0.005$ \\
\hline
\end{tabular}

Hayden Pass Area

\begin{tabular}{cccccccccc}
\hline RSC01 & 3 & 1.3 & 0.86 & 0.57 & 3.2 & 7.5 & 2.2 & 1.3 & 0.27 \\
RSC02 & 4 & 0.37 & 0.24 & 0.17 & 0.82 & 4.4 & 0.59 & 1.1 & 0.080 \\
\hline & & \multicolumn{8}{c}{ Pikes Peak Area } \\
\hline PPR01 & $<3$ & 11 & 8.1 & 1.4 & 1.4 & 21 & 12 & 1.5 & 2.5 \\
PPR02 & $<3$ & 11 & 6.9 & 1.8 & 1.8 & 22 & 12 & 1.7 & 2.3 \\
\hline & & \multicolumn{8}{c}{ Duplicate } \\
\hline RSC01R & $<3$ & 0.97 & 0.54 & 0.47 & 3.3 & 7.6 & 1.6 & 1.3 & 0.22 \\
\hline
\end{tabular}


Appendix 1. Chemical analysis of rocks from the Hayden Pass and Pikes Peak study areas.

\begin{tabular}{ccccccccccc}
\hline Site & $\mathrm{In}$ & $\mathrm{K}$ & $\mathrm{La}$ & $\mathrm{Li}$ & $\mathrm{Mg}$ & $\mathrm{Mn}$ & $\mathrm{Mo}$ & $\mathrm{Na}$ & $\mathrm{Nb}$ & $\mathrm{Nd}$ \\
& $\mathrm{ppm}$ & $\%$ & $\mathrm{ppm}$ & $\mathrm{ppm}$ & $\%$ & $\mathrm{ppm}$ & $\mathrm{ppm}$ & $\mathrm{ppm}$ & $\mathrm{ppm}$ & $\mathrm{ppm}$ \\
\hline \hline & & & & & & & & & & \\
Detection Limit & $<0.1$ & $<0.01$ & $<0.1$ & $<0.5$ & $<0.01$ & $<0.3$ & $<0.1$ & $<0.01$ & $<0.1$ & $<0.05$ \\
\hline
\end{tabular}

Hayden Pass Area

\begin{tabular}{ccccccccccc}
\hline RSC01 & $<0.1$ & 0.96 & 40 & 17 & 0.34 & 95 & 0.2 & 0.08 & 5.7 & 31 \\
RSC02 & $<0.1$ & 0.65 & 5.6 & 5.1 & 0.09 & 68 & 0.2 & 0.11 & 4.1 & 5.3 \\
\hline & & \multicolumn{8}{c}{ Pikes Peak Area } \\
\hline PPR01 & $<0.1$ & 5.4 & 160 & 26 & 0.04 & 160 & 1.9 & 2.5 & 55 & 110 \\
PPR02 & $<0.1$ & 5.0 & 140 & 62 & 0.15 & 420 & 2.2 & 2.8 & 63 & 88 \\
\hline & & \multicolumn{8}{c}{ Duplicate } \\
\hline RSC01R & $<0.1$ & 1.0 & 24 & 17 & 0.35 & 100 & 0.2 & 0.07 & 6.7 & 25 \\
\hline
\end{tabular}


Appendix 1. Chemical analysis of rocks from the Hayden Pass and Pikes Peak study areas.

\begin{tabular}{ccccccccccc}
\hline Site & $\mathrm{Ni}$ & $\mathrm{P}$ & $\mathrm{Pb}$ & $\mathrm{Pr}$ & $\mathrm{Rb}$ & $\mathrm{Re}$ & $\mathrm{Sb}$ & $\mathrm{Sc}$ & $\mathrm{Se}$ & $\mathrm{Sm}$ \\
& $\mathrm{ppm}$ & $\%$ & $\mathrm{ppm}$ & $\mathrm{ppm}$ & $\mathrm{ppm}$ & $\mathrm{ppm}$ & $\mathrm{ppm}$ & $\mathrm{ppm}$ & $\mathrm{ppm}$ & $\mathrm{ppm}$ \\
\hline \hline & & & & & & & & & & \\
Detection Limit & $<0.1$ & $<0.01$ & $<0.1$ & $<0.05$ & $<0.1$ & $<0.05$ & $<0.1$ & $<0.5$ & $<1$ & $<0.05$ \\
\hline
\end{tabular}

\begin{tabular}{|c|c|c|c|c|c|c|c|c|c|c|}
\hline \multicolumn{11}{|c|}{ Hayden Pass Area } \\
\hline RSC01 & 30 & 0.02 & 10 & 8.7 & 34 & $<0.05$ & $<0.1$ & 2 & $<1$ & 4.0 \\
\hline RSC02 & 5.4 & 0.02 & 5.2 & 1.3 & 18 & $<0.05$ & 0.2 & 1 & $<1$ & 0.91 \\
\hline \multicolumn{11}{|c|}{ Pikes Peak Area } \\
\hline PPR01 & 0.4 & 0.03 & 36 & 30 & 290 & $<0.05$ & $<0.1$ & 2 & $<1$ & 16 \\
\hline PPR02 & 0.5 & 0.05 & 33 & 25 & 290 & $<0.05$ & $<0.1$ & 5.0 & $<1$ & 15 \\
\hline \multicolumn{11}{|c|}{ Duplicate } \\
\hline RSC01R & 31 & 0.02 & 7.2 & 7.2 & 34 & $<0.05$ & $<0.1$ & 2 & $<1$ & 3.1 \\
\hline
\end{tabular}


Appendix 1. Chemical analysis of rocks from the Hayden Pass and Pikes Peak study areas.

\begin{tabular}{|c|c|c|c|c|c|c|c|c|c|c|}
\hline Site & $\begin{array}{c}\text { Sn } \\
\text { ppm }\end{array}$ & $\begin{array}{c}\mathrm{Sr} \\
\mathrm{ppm}\end{array}$ & $\begin{array}{c}\text { Tb } \\
\mathrm{ppm}\end{array}$ & $\begin{array}{c}\text { Te } \\
\mathrm{ppm}\end{array}$ & $\begin{array}{c}\text { Th } \\
\text { ppm }\end{array}$ & $\begin{array}{l}\mathrm{Ti} \\
\%\end{array}$ & $\begin{array}{c}\text { TI } \\
\text { ppm }\end{array}$ & $\begin{array}{l}\text { Tm } \\
\text { ppm }\end{array}$ & $\begin{array}{c}\text { U } \\
\text { ppm }\end{array}$ & $\begin{array}{c}\mathrm{V} \\
\mathrm{ppm}\end{array}$ \\
\hline Detection Limit & $<1$ & $<0.3$ & $<0.005$ & $<0.2$ & $<0.05$ & $<0.01$ & $<0.1$ & $<0.005$ & $<0.05$ & $<1$ \\
\hline
\end{tabular}

Hayden Pass Area

\begin{tabular}{ccccccccccc}
\hline RSC01 & $<1$ & 18 & 0.23 & $<0.2$ & 5.6 & 0.09 & 0.2 & 0.14 & 1.5 & 19 \\
RSC02 & $<1$ & 10 & 0.077 & $<0.2$ & 2.0 & 0.05 & 0.1 & 0.05 & 0.66 & 12 \\
\hline & & & \multicolumn{10}{c}{ Pikes Peak Area } \\
\hline PPR01 & 7.3 & 50 & 1.7 & $<0.2$ & 66 & 0.1 & 1.6 & 1.5 & 7.1 & $<1$ \\
PPR02 & 12 & 110 & 1.8 & $<0.2$ & 46 & 0.2 & 1.7 & 1.3 & 10 & 6 \\
\hline & & & & \multicolumn{7}{c}{ Duplicate } \\
\hline RSC01R & $<1$ & 15 & 0.15 & $<0.2$ & 5.3 & 0.08 & 0.2 & 0.098 & 1.4 & 20 \\
\hline
\end{tabular}


Appendix 1. Chemical analysis of rocks from the Hayden Pass and Pikes Peak study areas.

\begin{tabular}{ccccc}
\hline Site & $\mathrm{W}$ & $\mathrm{Y}$ & $\mathrm{Yb}$ & $\mathrm{Zn}$ \\
& $\mathrm{ppm}$ & $\mathrm{ppm}$ & $\mathrm{ppm}$ & $\mathrm{ppm}$ \\
\hline \hline & & & & \\
Detection Limit & $<0.1$ & $<0.1$ & $<0.05$ & $<3$ \\
\hline
\end{tabular}

\begin{tabular}{ccccc}
\multicolumn{5}{c}{ Hayden Pass Area } \\
\hline RSC01 & 0.2 & 7.6 & 0.68 & 48 \\
RSC02 & 0.2 & 1.9 & 0.3 & 10 \\
\hline \multicolumn{5}{c}{ Pikes Peak Area } \\
\hline PPR01 & 2.0 & 81 & 8.6 & 49 \\
PPR02 & 2.8 & 73 & 7.1 & 65 \\
\hline \multicolumn{5}{c}{ Duplicate } \\
\hline RSC01R & 0.4 & 5.4 & 0.61 & 50 \\
\hline
\end{tabular}


Appendix 2. Chemical analysis of soils from the Hayden Pass and Pikes Peak study areas, Colorado

\begin{tabular}{|c|c|c|c|c|c|c|}
\hline Site & $\begin{array}{l}\text { Latitute } \\
\text { Degree }\end{array}$ & $\begin{array}{c}\text { Longitute } \\
\text { Degree }\end{array}$ & $\begin{array}{c}\text { Elevation } \\
\text { Feet }\end{array}$ & Comments & $\begin{array}{c}\mathrm{Ag} \\
\mathrm{ppm}\end{array}$ & $\begin{array}{l}\mathrm{Al} \\
\% \\
\end{array}$ \\
\hline \multicolumn{2}{|c|}{ Detection Limit } & & & & $<0.02$ & $<0.01$ \\
\hline \multicolumn{7}{|c|}{ Hayden Pass } \\
\hline \multicolumn{7}{|c|}{ West Side } \\
\hline SSC3 & 38.2922 & 105.8494 & 10720 & brown, mostly silt and clay & 0.09 & 7.1 \\
\hline SSC4 & 38.2928 & 105.8522 & 10480 & similar with sl. organics & 0.07 & 6.5 \\
\hline SSC5 & 38.2931 & 105.8547 & 10380 & similar, mod. organics & 0.08 & 7.5 \\
\hline \multicolumn{7}{|c|}{ East Side } \\
\hline SSC2 & 38.2925 & 105.8478 & 10750 & brown, mostly silt and clay & 0.11 & 7.2 \\
\hline SSC1 & 38.2953 & 105.8483 & 10520 & brown, mostly silt and clay & 0.12 & 4.8 \\
\hline \multicolumn{7}{|c|}{ Pikes Peak } \\
\hline \multicolumn{7}{|c|}{ West Side } \\
\hline PPS3 & 38.8385 & 105.0462 & 14070 & brown, mostly clay & 0.18 & 7.9 \\
\hline PPS2 & 38.839 & 105.046 & 13970 & brown, mostly clay & 0.49 & 8.5 \\
\hline PPS4 & 38.8385 & 105.0488 & 13680 & brown, mostly clay & 0.32 & 8.6 \\
\hline PPS5 & 38.8482 & 105.0609 & 13130 & brown, some organic & 0.47 & 8.3 \\
\hline PPS1 & 38.8587 & 105.0669 & 13020 & brown, some organic & 0.46 & 7.2 \\
\hline \multicolumn{7}{|c|}{ East Side } \\
\hline PPS7 & 38.8409 & 105.0416 & 13920 & brown, some organic & 0.46 & 7.9 \\
\hline PPS8 & 38.8403 & 105.0413 & 13600 & brown, some organic & 1.0 & 8.1 \\
\hline PPS9 & 38.8395 & 105.0397 & 13530 & brown, some organic & 0.56 & 8.6 \\
\hline PPS10 & 38.8401 & 105.037 & 13200 & brown, some organic & 0.26 & 6.8 \\
\hline PPS6 & 38.8667 & 105.0631 & 12440 & brown, some organic & 1.4 & 8.4 \\
\hline \multicolumn{7}{|c|}{ Duplicate } \\
\hline SSC1R & & & & & 0.12 & 5.2 \\
\hline
\end{tabular}


Appendix 2. Chemical analysis of soils from the Hayden Pass and Pikes Peak study areas, Colorado

\begin{tabular}{|c|c|c|c|c|c|c|c|c|c|}
\hline Site & $\begin{array}{c}\text { As } \\
\mathrm{ppm}\end{array}$ & $\begin{array}{c}\mathrm{Au} \\
\mathrm{ppm}\end{array}$ & $\begin{array}{c}\mathrm{Ba} \\
\mathrm{ppm}\end{array}$ & $\begin{array}{c}\mathrm{Be} \\
\mathrm{ppm}\end{array}$ & $\begin{array}{c}\mathrm{Bi} \\
\mathrm{ppm}\end{array}$ & $\begin{array}{c}\mathrm{Ca} \\
\%\end{array}$ & $\begin{array}{c}\mathrm{Cd} \\
\mathrm{ppm}\end{array}$ & $\begin{array}{c}\mathrm{Ce} \\
\mathrm{ppm}\end{array}$ & $\begin{array}{c}\text { Co } \\
\text { ppm }\end{array}$ \\
\hline Detection & $<0.5$ & $<0.05$ & $<2$ & $<0.1$ & $<0.07$ & $<0.05$ & $<0.1$ & $<0.1$ & $<0.1$ \\
\hline \multicolumn{10}{|c|}{ Hayden Pass } \\
\hline \multicolumn{10}{|c|}{ West Side } \\
\hline SSC3 & 4 & $<0.05$ & 630 & 1.7 & 0.27 & 0.5 & 0.2 & 74 & 8.4 \\
\hline SSC4 & 5.4 & $<0.05$ & 700 & 1.4 & 0.32 & 0.61 & 0.3 & 58 & 9.6 \\
\hline SSC5 & 6.9 & $<0.05$ & 700 & 2.1 & 0.41 & 0.78 & 1.0 & 82 & 14 \\
\hline \multicolumn{10}{|c|}{ East Side } \\
\hline SSC2 & 4 & $<0.05$ & 690 & 1.2 & 0.35 & 0.5 & 0.2 & 73 & 7.2 \\
\hline SSC1 & 3 & $<0.05$ & 480 & 1.0 & 0.40 & 0.4 & $<0.1$ & 37 & 3.3 \\
\hline \multicolumn{10}{|c|}{ Pikes Peak } \\
\hline \multicolumn{10}{|c|}{ West Side } \\
\hline PPS3 & 4 & $<0.05$ & 610 & 6.8 & 0.87 & 0.52 & 0.2 & 340 & 8.3 \\
\hline PPS2 & $<0.5$ & 0.05 & 670 & 7.8 & 0.1 & 0.84 & 0.2 & 600 & 3.9 \\
\hline PPS4 & 4 & $<0.05$ & 600 & 6.9 & 0.40 & 0.60 & 0.4 & 430 & 5.7 \\
\hline PPS5 & 2 & $<0.05$ & 540 & 8.3 & 0.32 & 0.50 & 0.4 & 550 & 4.2 \\
\hline PPS1 & 5.0 & 0.06 & 490 & 5.8 & 0.38 & 0.51 & 0.6 & 300 & 3.8 \\
\hline \multicolumn{10}{|c|}{ East Side } \\
\hline PPS7 & 6.7 & $<0.05$ & 630 & 8.2 & 0.77 & 0.58 & 0.9 & 570 & 6.4 \\
\hline PPS8 & 11 & $<0.05$ & 560 & 6.0 & 0.68 & 0.66 & 0.8 & 380 & 7.0 \\
\hline PPS9 & 7.9 & $<0.05$ & 540 & 6.2 & 0.72 & 0.50 & 0.6 & 280 & 7.8 \\
\hline PPS10 & 5.9 & $<0.05$ & 480 & 4.9 & 0.44 & 0.5 & 0.7 & 260 & 4.9 \\
\hline PPS6 & 4 & 0.1 & 330 & 9.2 & 0.27 & 0.57 & 0.6 & 840 & 3.3 \\
\hline \multicolumn{10}{|c|}{ Duplicate } \\
\hline SSC1R & 3 & $<0.05$ & 520 & 0.9 & 0.1 & 0.4 & $<0.1$ & 50 & 3.4 \\
\hline
\end{tabular}


Appendix 2. Chemical analysis of soils from the Hayden Pass and Pikes Peak study areas, Colorado

\begin{tabular}{|c|c|c|c|c|c|c|c|c|}
\hline Site & $\begin{array}{c}\mathrm{Cr} \\
\mathrm{ppm}\end{array}$ & $\begin{array}{c}\text { Cs } \\
\text { ppm }\end{array}$ & $\begin{array}{c}\mathrm{Cu} \\
\mathrm{ppm}\end{array}$ & $\begin{array}{c}\text { Dy } \\
\text { ppm }\end{array}$ & $\begin{array}{c}\text { Er } \\
\text { ppm }\end{array}$ & $\begin{array}{c}\text { Eu } \\
\text { ppm }\end{array}$ & $\begin{array}{c}\mathrm{Fe} \\
\% \\
\end{array}$ & $\begin{array}{c}\mathrm{Ga} \\
\mathrm{ppm}\end{array}$ \\
\hline Detection & $<<1$ & $<0.1$ & $<3$ & $<0.005$ & $<0.005$ & $<0.005$ & $<0.01$ & $<0.1$ \\
\hline \multicolumn{9}{|c|}{ Hayden Pass } \\
\hline \multicolumn{9}{|c|}{ West Side } \\
\hline SSC3 & 49 & 3.6 & 20 & 3.0 & 1.8 & 1.1 & 2.6 & 16 \\
\hline SSC4 & 45 & 4.0 & 20 & 2.9 & 1.6 & 0.98 & 2.2 & 14 \\
\hline SSC5 & 51 & 4.7 & 30 & 3.4 & 2.1 & 1.3 & 2.8 & 16 \\
\hline \multicolumn{9}{|c|}{ East Side } \\
\hline SSC2 & 52 & 4.1 & 20 & 3.1 & 1.7 & 1.1 & 2.4 & 17 \\
\hline SSC1 & 46 & 2.6 & 9 & 1.9 & 1.3 & 0.62 & 1.5 & 11 \\
\hline \multicolumn{9}{|c|}{ Pikes Peak } \\
\hline \multicolumn{9}{|c|}{ West Side } \\
\hline PPS3 & 32 & 5.5 & 30 & 18 & 11 & 2.2 & 3.5 & 20 \\
\hline PPS2 & 10 & 3.5 & 8 & 32 & 22 & 2.6 & 3.8 & 25 \\
\hline PPS4 & 26 & 6.1 & 20 & 24 & 16 & 1.9 & 3.4 & 23 \\
\hline PPS5 & 23 & 5.4 & 10 & 27 & 17 & 1.6 & 3.9 & 24 \\
\hline PPS1 & 25 & 5.1 & 10 & 18 & 14 & 1.2 & 2.8 & 22 \\
\hline \multicolumn{9}{|c|}{ East Side } \\
\hline PPS7 & 31 & 5.1 & 20 & 31 & 22 & 2.1 & 3.5 & 20 \\
\hline PPS8 & 38 & 7.0 & 30 & 28 & 21 & 1.9 & 3.8 & 22 \\
\hline PPS9 & 36 & 8.0 & 20 & 21 & 15 & 2.0 & 4.1 & 23 \\
\hline PPS10 & 31 & 5.5 & 20 & 13 & 8.3 & 1.2 & 2.9 & 17 \\
\hline PPS6 & 19 & 4.6 & 10 & 46 & 38 & 1.3 & 3.7 & 29 \\
\hline \multicolumn{9}{|c|}{ Duplicate } \\
\hline SSC1R & 45 & 2.6 & 9 & 1.9 & 1.2 & 0.63 & 1.4 & 11 \\
\hline
\end{tabular}


Appendix 2. Chemical analysis of soils from the Hayden Pass and Pikes Peak study areas, Colorado

\begin{tabular}{|c|c|c|c|c|c|c|c|c|}
\hline Site & $\begin{array}{c}\mathrm{Gd} \\
\mathrm{ppm}\end{array}$ & $\begin{array}{c}\mathrm{Ge} \\
\mathrm{ppm}\end{array}$ & $\begin{array}{c}\text { Ho } \\
\text { ppm }\end{array}$ & $\begin{array}{c}\text { In } \\
\text { ppm }\end{array}$ & $\begin{array}{l}\mathrm{K} \\
\% \\
\end{array}$ & $\begin{array}{c}\text { La } \\
\text { ppm }\end{array}$ & $\begin{array}{c}\mathrm{Li} \\
\mathrm{ppm}\end{array}$ & $\begin{array}{c}\mathrm{Mg} \\
\%\end{array}$ \\
\hline Detection & $<0.005$ & $<0.1$ & $<0.005$ & $<0.1$ & $<0.01$ & $<0.1$ & $<0.5$ & $<0.01$ \\
\hline \multicolumn{9}{|c|}{ Hayden Pass } \\
\hline \multicolumn{9}{|c|}{ West Side } \\
\hline SSC3 & 4.1 & 1.0 & 0.61 & $<0.1$ & 2.2 & 36 & 30 & 0.40 \\
\hline SSC4 & 3.5 & 0.9 & 0.56 & 0.1 & 1.8 & 32 & 33 & 0.46 \\
\hline SSC5 & 4.8 & 1.0 & 0.73 & 0.1 & 2.1 & 40 & 42 & 0.56 \\
\hline \multicolumn{9}{|c|}{ East Side } \\
\hline SSC2 & 3.9 & 0.8 & 0.57 & $<0.1$ & 1.9 & 36 & 32 & 0.45 \\
\hline SSC1 & 2.5 & 1.3 & 0.42 & $<0.1$ & 1.4 & 21 & 17 & 0.26 \\
\hline \multicolumn{9}{|c|}{ Pikes Peak } \\
\hline \multicolumn{9}{|c|}{ West Side } \\
\hline PPS3 & 20 & 1.3 & 3.7 & 0.3 & 2.9 & 180 & 42 & 0.61 \\
\hline PPS2 & 36 & 1.1 & 7.0 & 0.3 & 3.9 & 310 & 42 & 0.32 \\
\hline PPS4 & 25 & 1.2 & 5.1 & 0.3 & 3.5 & 220 & 53 & 0.54 \\
\hline PPS5 & 30 & 1.3 & 5.6 & 0.3 & 3.4 & 280 & 55 & 0.43 \\
\hline PPS1 & 18 & 1.4 & 4.2 & 0.2 & 2.9 & 160 & 52 & 0.38 \\
\hline \multicolumn{9}{|c|}{ East Side } \\
\hline PPS7 & 31 & 1.0 & 7.0 & 0.4 & 3.0 & 300 & 64 & 0.52 \\
\hline PPS8 & 26 & 1.3 & 6.3 & 0.3 & 2.5 & 210 & 65 & 0.65 \\
\hline PPS9 & 20 & 1.3 & 4.6 & 0.5 & 2.6 & 160 & 66 & 0.74 \\
\hline PPS10 & 13 & 1.2 & 2.7 & 0.2 & 2.2 & 140 & 47 & 0.53 \\
\hline PPS6 & 39 & 1.2 & 11 & 0.3 & 3.0 & 400 & 89 & 0.37 \\
\hline \multicolumn{9}{|c|}{ Duplicate } \\
\hline SSC1R & 2.5 & 1.4 & 0.42 & $<0.1$ & 1.5 & 24 & 18 & 0.27 \\
\hline
\end{tabular}


Appendix 2. Chemical analysis of soils from the Hayden Pass and Pikes Peak study areas, Colorado

\begin{tabular}{|c|c|c|c|c|c|c|c|c|}
\hline Site & $\begin{array}{c}\mathrm{Mn} \\
\mathrm{ppm}\end{array}$ & $\begin{array}{l}\text { Mo } \\
\text { ppm }\end{array}$ & $\begin{array}{c}\mathrm{Na} \\
\%\end{array}$ & $\begin{array}{c}\mathrm{Nb} \\
\mathrm{ppm}\end{array}$ & $\begin{array}{c}\mathrm{Nd} \\
\mathrm{ppm}\end{array}$ & $\begin{array}{c}\mathrm{Ni} \\
\mathrm{ppm}\end{array}$ & $\begin{array}{l}\mathrm{P} \\
\% \\
\end{array}$ & $\begin{array}{c}\mathrm{Pb} \\
\mathrm{ppm}\end{array}$ \\
\hline Detection & $<0.3$ & $<0.1$ & $<0.01$ & $<0.1$ & $<0.05$ & $<0.1$ & $<0.01$ & $<0.1$ \\
\hline \multicolumn{9}{|c|}{ Hayden Pass } \\
\hline \multicolumn{9}{|c|}{ West Side } \\
\hline SSC3 & 460 & 1.1 & 0.89 & 18 & 29 & 16 & 0.03 & 26 \\
\hline SSC4 & 630 & 1.2 & 1.0 & 12 & 26 & 14 & 0.04 & 37 \\
\hline SSC5 & 1500 & 1.4 & 0.95 & 17 & 34 & 21 & 0.08 & 50 \\
\hline \multicolumn{9}{|c|}{ East Side } \\
\hline SSC2 & 610 & 1.4 & 1.0 & 20 & 30 & 14 & 0.05 & 23 \\
\hline SSC1 & 160 & 1.3 & 0.70 & 13 & 17 & 8.7 & 0.02 & 15 \\
\hline \multicolumn{9}{|c|}{ Pikes Peak } \\
\hline \multicolumn{9}{|c|}{ West Side } \\
\hline PPS3 & 1400 & 3.4 & 1.6 & 60 & 130 & 11 & 0.18 & 56 \\
\hline PPS2 & 950 & 2.7 & 2.6 & 160 & 240 & 4.7 & 0.11 & 50 \\
\hline PPS4 & 730 & 2.9 & 2.0 & 110 & 170 & 8.9 & 0.14 & 66 \\
\hline PPS5 & 740 & 4.5 & 2.0 & 150 & 220 & 7.5 & 0.12 & 57 \\
\hline PPS1 & 520 & 2.7 & 2.0 & 150 & 120 & 7.6 & 0.10 & 59 \\
\hline \multicolumn{9}{|c|}{ East Side } \\
\hline PPS7 & 720 & 3.5 & 1.8 & 140 & 210 & 10 & 0.12 & 150 \\
\hline PPS8 & 690 & 4.6 & 1.3 & 84 & 150 & 13 & 0.20 & 110 \\
\hline PPS9 & 1100 & 5.6 & 1.2 & 70 & 110 & 13 & 0.19 & 68 \\
\hline PPS10 & 420 & 3.6 & 1.1 & 38 & 89 & 11 & 0.17 & 50 \\
\hline PPS6 & 570 & 4.1 & 2.3 & 520 & 240 & 6.6 & 0.07 & 84 \\
\hline \multicolumn{9}{|c|}{ Duplicate } \\
\hline SSC1R & 160 & 0.9 & 0.76 & 11 & 20 & 9.0 & 0.02 & 16 \\
\hline
\end{tabular}


Appendix 2. Chemical analysis of soils from the Hayden Pass and Pikes Peak study areas, Colorado

\begin{tabular}{|c|c|c|c|c|c|c|c|c|}
\hline Site & $\begin{array}{c}\mathrm{Pr} \\
\mathrm{ppm}\end{array}$ & $\begin{array}{c}\mathrm{Rb} \\
\mathrm{ppm}\end{array}$ & $\begin{array}{c}\mathrm{Re} \\
\mathrm{ppm}\end{array}$ & $\begin{array}{c}\mathrm{Sb} \\
\mathrm{ppm}\end{array}$ & $\begin{array}{c}\text { Sc } \\
\text { ppm }\end{array}$ & $\begin{array}{c}\mathrm{Se} \\
\mathrm{ppm}\end{array}$ & $\begin{array}{c}\text { Sm } \\
\mathrm{ppm}\end{array}$ & $\begin{array}{c}\text { Sn } \\
\mathrm{ppm}\end{array}$ \\
\hline Detection & $<0.05$ & $<0.1$ & $<0.05$ & $<0.1$ & $<0.5$ & $<<1$ & $<0.05$ & $<<1$ \\
\hline \multicolumn{9}{|c|}{ Hayden Pass } \\
\hline \multicolumn{9}{|c|}{ West Side } \\
\hline SSC3 & 7.6 & 90 & $<0.05$ & 0.4 & 8.2 & $<1$ & 5.4 & 2 \\
\hline SSC4 & 6.8 & 84 & $<0.05$ & 0.5 & 7.1 & $<1$ & 4.7 & 2 \\
\hline SSC5 & 8.5 & 91 & $<0.05$ & 0.6 & 9.7 & $<1$ & 6.4 & 2 \\
\hline \multicolumn{9}{|c|}{ East Side } \\
\hline SSC2 & 8.0 & 94 & $<0.05$ & 0.6 & 8.2 & $<1$ & 5.4 & 2 \\
\hline SSC1 & 4.7 & 66 & $<0.05$ & 0.4 & 5.2 & $<1$ & 3.5 & 2 \\
\hline \multicolumn{9}{|c|}{ Pikes Peak } \\
\hline \multicolumn{9}{|c|}{ West Side } \\
\hline PPS3 & 36 & 170 & $<0.05$ & 0.6 & 10 & $<1$ & 24 & 17 \\
\hline PPS2 & 65 & 210 & $<0.05$ & 0.2 & 12 & $<1$ & 45 & 12 \\
\hline PPS4 & 46 & 210 & $<0.05$ & 0.5 & 10 & $<1$ & 32 & 12 \\
\hline PPS5 & 58 & 220 & $<0.05$ & 0.5 & 12 & $<1$ & 39 & 10 \\
\hline PPS1 & 32 & 220 & $<0.05$ & 0.6 & 9.2 & $<1$ & 22 & 11 \\
\hline \multicolumn{9}{|c|}{ East Side } \\
\hline PPS7 & 58 & 190 & $<0.05$ & 1.0 & 9.8 & $<1$ & 38 & 16 \\
\hline PPS8 & 40 & 170 & $<0.05$ & 1.5 & 10 & $<1$ & 28 & 16 \\
\hline PPS9 & 30 & 180 & $<0.05$ & 1.0 & 11 & $<1$ & 21 & 12 \\
\hline PPS10 & 26 & 140 & $<0.05$ & 1.0 & 7.5 & $<1$ & 16 & 6.8 \\
\hline PPS6 & 69 & 240 & $<0.05$ & 0.5 & 12 & $<1$ & 42 & 22 \\
\hline \multicolumn{9}{|c|}{ Duplicate } \\
\hline SSC1R & 5.3 & 66 & $<0.05$ & 0.3 & 5.0 & $<1$ & 3.5 & 2 \\
\hline
\end{tabular}


Appendix 2. Chemical analysis of soils from the Hayden Pass and Pikes Peak study areas, Colorado

\begin{tabular}{|c|c|c|c|c|c|c|c|c|}
\hline Site & $\begin{array}{c}\mathrm{Sr} \\
\mathrm{ppm}\end{array}$ & $\begin{array}{c}\mathrm{Tb} \\
\mathrm{ppm}\end{array}$ & $\begin{array}{c}\text { Te } \\
\text { ppm }\end{array}$ & $\begin{array}{c}\text { Th } \\
\text { ppm }\end{array}$ & $\begin{array}{l}\mathrm{Ti} \\
\% \\
\end{array}$ & $\begin{array}{c}\mathrm{TI} \\
\mathrm{ppm}\end{array}$ & $\begin{array}{l}\mathrm{Tm} \\
\mathrm{ppm}\end{array}$ & $\begin{array}{c}\text { U } \\
\mathrm{ppm}\end{array}$ \\
\hline Detection & $<0.3$ & $<0.005$ & $<0.2$ & $<0.05$ & $<0.01$ & $<0.1$ & $<0.005$ & $<0.05$ \\
\hline \multicolumn{9}{|c|}{ Hayden Pass } \\
\hline \multicolumn{9}{|c|}{ West Side } \\
\hline SSC3 & 120 & 0.56 & $<0.2$ & 11 & 0.4 & 0.6 & 0.32 & 3.9 \\
\hline SSC4 & 150 & 0.47 & $<0.2$ & 8.8 & 0.4 & 0.6 & 0.28 & 2.9 \\
\hline SSC5 & 150 & 0.61 & $<0.2$ & 11 & 0.4 & 0.7 & 0.36 & 3.7 \\
\hline \multicolumn{9}{|c|}{ East Side } \\
\hline SSC2 & 140 & 0.48 & $<0.2$ & 11 & 0.5 & 0.7 & 0.34 & 3.6 \\
\hline SSC1 & 93 & 0.34 & $<0.2$ & 7.1 & 0.4 & 0.6 & 0.25 & 2.4 \\
\hline \multicolumn{9}{|c|}{ Pikes Peak } \\
\hline \multicolumn{9}{|c|}{ West Side } \\
\hline PPS3 & 120 & 3.0 & $<0.2$ & 51 & 0.4 & 1.1 & 1.9 & 14 \\
\hline PPS2 & 110 & 5.4 & $<0.2$ & 65 & 0.5 & 1.2 & 3.7 & 12 \\
\hline PPS4 & 110 & 3.9 & $<0.2$ & 59 & 0.4 & 1.3 & 2.8 & 12 \\
\hline PPS5 & 92 & 4.4 & $<0.2$ & 62 & 0.4 & 1.4 & 2.9 & 9.8 \\
\hline PPS1 & 100 & 2.9 & $<0.2$ & 46 & 0.3 & 1.2 & 2.6 & 10 \\
\hline \multicolumn{9}{|c|}{ East Side } \\
\hline PPS7 & 120 & 5.1 & $<0.2$ & 94 & 0.4 & 1.2 & 3.9 & 18 \\
\hline PPS8 & 120 & 4.2 & $<0.2$ & 61 & 0.3 & 1.2 & 3.7 & 16 \\
\hline PPS9 & 99 & 3.2 & $<0.2$ & 44 & 0.3 & 1.1 & 2.6 & 16 \\
\hline PPS10 & 98 & 2.1 & $<0.2$ & 45 & 0.3 & 0.9 & 1.5 & 9.7 \\
\hline PPS6 & 75 & 6.7 & $<0.2$ & 140 & 0.3 & 1.4 & 7.2 & 29 \\
\hline \multicolumn{9}{|c|}{ Duplicate } \\
\hline SSC1R & 94 & 0.32 & $<0.2$ & 8.1 & 0.4 & 0.6 & 0.22 & 2.5 \\
\hline
\end{tabular}


Appendix 2. Chemical analysis of soils from the Hayden Pass and Pikes Peak study areas, Colorado

\begin{tabular}{|c|c|c|c|c|c|}
\hline Site & $\begin{array}{c}\mathrm{V} \\
\mathrm{ppm}\end{array}$ & $\begin{array}{c}\text { W } \\
\text { ppm }\end{array}$ & $\begin{array}{c}\mathrm{Y} \\
\mathrm{ppm}\end{array}$ & $\begin{array}{c}\mathrm{Yb} \\
\mathrm{ppm}\end{array}$ & $\begin{array}{c}\mathrm{Zn} \\
\mathrm{ppm}\end{array}$ \\
\hline Detection & $<<1$ & $<0.1$ & $<0.1$ & $<0.05$ & $<3$ \\
\hline & \multicolumn{5}{|c|}{ Hayden Pass } \\
\hline & \multicolumn{5}{|c|}{ West Side } \\
\hline SSC3 & 67 & 1.4 & 17 & 2.1 & 48 \\
\hline SSC4 & 61 & 1.1 & 16 & 1.6 & 69 \\
\hline \multirow[t]{2}{*}{ SSC5 } & 70 & 1.8 & 24 & 2.3 & 120 \\
\hline & \multicolumn{5}{|c|}{ East Side } \\
\hline SSC2 & 72 & 2.1 & 16 & 1.7 & 69 \\
\hline \multirow[t]{3}{*}{ SSC1 } & 60 & 1.5 & 11 & 1.2 & 20 \\
\hline & \multicolumn{5}{|c|}{ Pikes Peak } \\
\hline & \multicolumn{5}{|c|}{ West Side } \\
\hline PPS3 & 60 & 3.5 & 110 & 11 & 160 \\
\hline PPS2 & 27 & 5.1 & 220 & 22 & 140 \\
\hline PPS4 & 44 & 5.2 & 140 & 16 & 140 \\
\hline PPS5 & 38 & 4.9 & 150 & 16 & 160 \\
\hline \multirow[t]{2}{*}{ PPS1 } & 38 & 4.2 & 120 & 15 & 130 \\
\hline & \multicolumn{5}{|c|}{ East Side } \\
\hline PPS7 & 50 & 4.8 & 220 & 24 & 200 \\
\hline PPS8 & 54 & 4.4 & 250 & 21 & 200 \\
\hline PPS9 & 60 & 4.6 & 160 & 15 & 210 \\
\hline PPS10 & 49 & 2.8 & 81 & 8.0 & 130 \\
\hline \multirow[t]{2}{*}{ PPS6 } & 28 & 8.2 & 420 & 42 & 150 \\
\hline & \multicolumn{5}{|c|}{ Duplicate } \\
\hline SSC1R & 59 & 0.8 & 11 & 1.2 & 30 \\
\hline
\end{tabular}


Appendix 3. Chemical analysis of the $\mathrm{MgCl}_{2}$ extracts of soils from the Hayden Pass and Pikes Peak study areas. All values in ppm.

\begin{tabular}{|c|c|c|c|c|c|c|}
\hline Site & $\begin{array}{l}\text { Latitude } \\
\text { Degree }\end{array}$ & $\begin{array}{l}\text { Longitude } \\
\text { Degree }\end{array}$ & Comments & $\mathrm{Ag}$ & $\mathrm{Al}$ & As \\
\hline \multirow[t]{3}{*}{ Detection Limit } & & & & $<0.6$ & $<0.4$ & $<0.2$ \\
\hline & \multicolumn{6}{|c|}{ Hayden Pass } \\
\hline & \multicolumn{6}{|c|}{ West Side } \\
\hline SSC3 & 38.2922 & 105.8494 & brown, mostly silt and clay & $<0.6$ & 18.9 & $<0.2$ \\
\hline SSC4 & 38.2928 & 105.8522 & similar with sl. organics & $<0.6$ & 61.8 & $<0.2$ \\
\hline \multirow[t]{2}{*}{ SSC5 } & 38.2931 & 105.8547 & similar, mod. organics & $<0.6$ & 15.1 & $<0.2$ \\
\hline & \multicolumn{6}{|c|}{ East Side } \\
\hline SSC2 & 38.2925 & 105.8478 & brown, mostly silt and clay & $<0.6$ & 234 & $<0.2$ \\
\hline \multirow[t]{2}{*}{ SSC1 } & 38.2953 & 105.8483 & brown, mostly silt and clay & $<0.6$ & 201 & 0.4 \\
\hline & \multicolumn{6}{|c|}{ Pikes Peak } \\
\hline & \multicolumn{6}{|c|}{ West Side } \\
\hline PPS3 & 38.8385 & 105.0462 & brown, mostly clay & $<0.6$ & 302 & 0.7 \\
\hline PPS2 & 38.839 & 105.046 & brown, mostly clay & $<0.6$ & 2.30 & $<0.2$ \\
\hline PPS4 & 38.8385 & 105.0488 & brown, mostly clay & $<0.6$ & 32.1 & $<0.2$ \\
\hline PPS5 & 38.8482 & 105.0609 & brown, some organic & $<0.6$ & 116 & $<0.2$ \\
\hline \multirow[t]{2}{*}{ PPS1 } & 38.8587 & 105.0669 & brown, some organic & $<0.6$ & 102 & $<0.2$ \\
\hline & \multicolumn{6}{|c|}{ East Side } \\
\hline PPS7 & 38.8409 & 105.0416 & brown, some organic & $<0.6$ & 71.1 & $<0.2$ \\
\hline PPS8 & 38.8403 & 105.0413 & brown, some organic & $<0.6$ & 134 & $<0.2$ \\
\hline PPS9 & 38.8395 & 105.0397 & brown, some organic & $<0.6$ & 333 & $<0.2$ \\
\hline PPS10 & 38.8401 & 105.037 & brown, some organic & $<0.6$ & 194 & $<0.2$ \\
\hline \multirow[t]{2}{*}{ PPS6 } & 38.8667 & 105.0631 & brown, some organic & $<0.6$ & 43.5 & $<0.2$ \\
\hline & \multicolumn{6}{|c|}{ Duplicate } \\
\hline SSC1R & & & & $<0.6$ & 169 & $<0.2$ \\
\hline PPS1R & & & & $<0.6$ & 72.2 & $<0.2$ \\
\hline
\end{tabular}


Appendix 3. Chemical analysis of the $\mathrm{MgCl}_{2}$ extracts of soils from the Hayden Pass and Pikes Peak study areas. All values in ppm.

\begin{tabular}{|c|c|c|c|c|c|c|c|c|c|}
\hline Site & $\mathrm{Ba}$ & $\mathrm{Be}$ & $\mathrm{Bi}$ & $\mathrm{Ca}$ & $\mathrm{Cd}$ & Co & $\mathrm{Cr}$ & Cs & $\mathrm{Cu}$ \\
\hline Detection Limit & $<0.04$ & $<0.01$ & $<0.04$ & $<40$ & $<0.004$ & $<0.004$ & $<0.2$ & $<0.004$ & $<0.1$ \\
\hline & \multicolumn{9}{|c|}{ Hayden Pass } \\
\hline & \multicolumn{9}{|c|}{ West Side } \\
\hline SSC3 & 27.5 & 0.01 & $<0.04$ & 840 & 0.11 & 0.74 & $<0.2$ & $<0.004$ & $<0.1$ \\
\hline SSC4 & 33.8 & $<0.01$ & $<0.04$ & 620 & 0.11 & 0.62 & $<0.2$ & $<0.004$ & $<0.1$ \\
\hline \multirow[t]{2}{*}{ SSC5 } & 44.4 & $<0.01$ & $<0.04$ & 2320 & 0.44 & 0.48 & $<0.2$ & $<0.004$ & $<0.1$ \\
\hline & \multicolumn{9}{|c|}{ East Side } \\
\hline$\overline{S S C 2}$ & 39.3 & 0.03 & $<0.04$ & 483 & 0.10 & 0.92 & $<0.2$ & $<0.004$ & $<0.1$ \\
\hline \multirow[t]{2}{*}{ SSC1 } & 36.2 & 0.02 & $<0.04$ & 987 & 0.05 & 0.74 & 0.2 & $<0.004$ & 0.4 \\
\hline & \multicolumn{9}{|c|}{ Pikes Peak } \\
\hline & \multicolumn{9}{|c|}{ West Side } \\
\hline PPS3 & 11.8 & 0.05 & $<0.04$ & 535 & 0.06 & 0.70 & 0.2 & $<0.004$ & $<0.1$ \\
\hline PPS2 & 33.0 & $<0.01$ & $<0.04$ & 1230 & 0.07 & 1.15 & 0.3 & $<0.004$ & $<0.1$ \\
\hline PPS4 & 9.06 & 0.02 & $<0.04$ & 728 & 0.10 & 0.75 & 0.2 & $<0.004$ & $<0.1$ \\
\hline PPS5 & 16.3 & 0.04 & $<0.04$ & 828 & 0.20 & 0.60 & 0.2 & $<0.004$ & $<0.1$ \\
\hline \multirow[t]{2}{*}{ PPS1 } & 18.0 & 0.02 & $<0.04$ & 673 & 0.22 & 0.47 & $<0.2$ & $<0.004$ & $<0.1$ \\
\hline & \multicolumn{9}{|c|}{ East Side } \\
\hline PPS7 & 36.0 & 0.01 & $<0.04$ & 963 & 0.45 & 0.80 & 0.3 & $<0.004$ & $<0.1$ \\
\hline PPS8 & 53.2 & 0.04 & $<0.04$ & 2790 & 0.48 & 0.90 & 0.3 & $<0.004$ & $<0.1$ \\
\hline PPS9 & 40.3 & 0.1 & $<0.04$ & 1780 & 0.39 & 0.96 & 0.3 & $<0.004$ & $<0.1$ \\
\hline PPS10 & 31.6 & 0.05 & $<0.04$ & 1610 & 0.52 & 1.32 & 0.5 & $<0.004$ & $<0.1$ \\
\hline \multirow[t]{2}{*}{ PPS6 } & 21.5 & 0.02 & $<0.04$ & 2430 & 0.40 & 0.93 & 0.2 & $<0.004$ & $<0.1$ \\
\hline & \multicolumn{9}{|c|}{ Duplicate } \\
\hline$\overline{\text { SSC1R }}$ & 35.3 & 0.02 & $<0.04$ & 836 & 0.04 & 0.88 & 0.3 & $<0.004$ & $<0.1$ \\
\hline PPS1R & 19.0 & 0.02 & $<0.04$ & 716 & 0.25 & 0.48 & $<0.2$ & $<0.004$ & $<0.1$ \\
\hline
\end{tabular}


Appendix 3. Chemical analysis of the $\mathrm{MgCl}_{2}$ extracts of soils from the Hayden Pass and Pikes Peak study areas. All values in ppm.

\begin{tabular}{|c|c|c|c|c|c|c|c|c|c|}
\hline Site & $\mathrm{Fe}$ & $\mathrm{Ga}$ & Ge & $\mathrm{K}$ & $\mathrm{Li}$ & $\mathrm{Mn}$ & Mo & $\mathrm{Na}$ & $\mathrm{Ni}$ \\
\hline Detection Limit & $<<10$ & $<0.01$ & $\overline{c<0.01}$ & $<6$ & $<0.2$ & 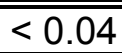 & $\overline{c<0.4}$ & $<<20$ & $<0.08$ \\
\hline & \multicolumn{9}{|c|}{ Hayden Pass } \\
\hline & \multicolumn{9}{|c|}{ West Side } \\
\hline SSC3 & $<10$ & $<0.01$ & $<0.01$ & 80.9 & $<0.2$ & 26.6 & $<0.4$ & $<20$ & 0.8 \\
\hline SSC4 & $<10$ & $<0.01$ & $<0.01$ & 60.3 & $<0.2$ & 28.4 & $<0.4$ & $<20$ & 0.6 \\
\hline \multirow[t]{2}{*}{ SSC5 } & $<10$ & $<0.01$ & $<0.01$ & 255 & $<0.2$ & 22.4 & $<0.4$ & $<20$ & 0.8 \\
\hline & \multicolumn{9}{|c|}{ East Side } \\
\hline$\overline{S S C 2}$ & 12 & $<0.01$ & $<0.01$ & 62.7 & $<0.2$ & 68.7 & $<0.4$ & $<20$ & 0.8 \\
\hline \multirow[t]{2}{*}{ SSC1 } & 22 & 0.01 & $<0.01$ & 37.1 & $<0.2$ & 21.4 & $<0.4$ & $<20$ & 0.8 \\
\hline & \multicolumn{9}{|c|}{ Pikes Peak } \\
\hline & \multicolumn{9}{|c|}{ West Side } \\
\hline PPS3 & $<10$ & 0.09 & $<0.01$ & 52.9 & $<0.2$ & 7.3 & $<0.4$ & $<20$ & 0.6 \\
\hline PPS2 & $<10$ & 0.04 & $<0.01$ & 52.8 & $<0.2$ & 4.3 & $<0.4$ & $<20$ & 1.2 \\
\hline PPS4 & $<10$ & 0.04 & $<0.01$ & 34.0 & $<0.2$ & 1.3 & $<0.4$ & $<20$ & 0.7 \\
\hline PPS5 & $<10$ & 0.1 & $<0.01$ & 58.9 & $<0.2$ & 4.1 & $<0.4$ & $<20$ & 0.6 \\
\hline \multirow[t]{2}{*}{ PPS1 } & $<10$ & 0.02 & $<0.01$ & 61.8 & $<0.2$ & 6.2 & $<0.4$ & $<20$ & 0.5 \\
\hline & \multicolumn{9}{|c|}{ East Side } \\
\hline PPS7 & $<10$ & 0.05 & $<0.01$ & 53.1 & $<0.2$ & 17.4 & $<0.4$ & 95.2 & 0.8 \\
\hline PPS8 & $<10$ & 0.04 & $<0.01$ & 63.6 & $<0.2$ & 9.5 & $<0.4$ & 35.0 & 1.1 \\
\hline PPS9 & $<10$ & 0.08 & $<0.01$ & 271 & $<0.2$ & 37.7 & $<0.4$ & $<20$ & 1.2 \\
\hline PPS10 & $<10$ & 0.03 & $<0.01$ & 326 & $<0.2$ & 24.8 & $<0.4$ & 37.9 & 1.4 \\
\hline \multirow[t]{2}{*}{ PPS6 } & $<10$ & 0.04 & $<0.01$ & 111 & $<0.2$ & 8.0 & $<0.4$ & $<20$ & 1.0 \\
\hline & \multicolumn{9}{|c|}{ Duplicate } \\
\hline SSC1R & 20 & $<0.01$ & $<0.01$ & 38.1 & $<0.2$ & 14.5 & $<0.4$ & $<20$ & 1.0 \\
\hline PPS1R & $<10$ & 0.02 & $<0.01$ & 60.9 & $<0.2$ & 6.1 & $<0.4$ & $<20$ & 0.4 \\
\hline
\end{tabular}


Appendix 3. Chemical analysis of the $\mathrm{MgCl}_{2}$ extracts of soils from the Hayden Pass and Pikes Peak study areas. All values in ppm.

\begin{tabular}{|c|c|c|c|c|c|c|c|c|c|}
\hline Site & $\mathrm{Pb}$ & $\mathrm{Rb}$ & $\mathrm{Sb}$ & $\mathrm{Se}$ & $\mathrm{Sr}$ & TI & $U$ & $\mathrm{~V}$ & $\mathrm{Zn}$ \\
\hline Detection Limit & $<0.01$ & $\bar{c}<0.002$ & $<0.06$ & $<<0.2$ & $<0.1$ & $<0.02$ & $\overline{c<}<0.02$ & $\overline{c<0.1}$ & $<0.1$ \\
\hline & \multicolumn{9}{|c|}{ Hayden Pass } \\
\hline & \multicolumn{9}{|c|}{ West Side } \\
\hline SSC3 & 1.4 & 0.15 & 0.27 & $<0.2$ & 5.71 & $<0.02$ & $<0.02$ & $<0.1$ & 0.3 \\
\hline SSC4 & 2.0 & 0.18 & 0.22 & $<0.2$ & 3.90 & $<0.02$ & $<0.02$ & $<0.1$ & 0.3 \\
\hline \multirow[t]{2}{*}{ SSC5 } & $<0.01$ & 0.19 & 0.2 & $<0.2$ & 14.5 & $<0.02$ & $<0.02$ & $<0.1$ & 2.9 \\
\hline & \multicolumn{9}{|c|}{ East Side } \\
\hline SSC2 & 1.6 & 0.12 & 0.35 & $<0.2$ & 3.41 & $<0.02$ & $<0.02$ & $<0.1$ & 2.4 \\
\hline \multirow[t]{2}{*}{ SSC1 } & 2.3 & 0.10 & 0.51 & $<0.2$ & 5.09 & $<0.02$ & $<0.02$ & $<0.1$ & 1 \\
\hline & \multicolumn{9}{|c|}{ Pikes Peak } \\
\hline & \multicolumn{9}{|c|}{ West Side } \\
\hline PPS3 & 2.3 & 0.26 & 0.1 & 0.2 & 2.52 & $<0.02$ & 0.04 & 0.2 & 1 \\
\hline PPS2 & $<0.01$ & 0.11 & 0.1 & $<0.2$ & 6.67 & $<0.02$ & $<0.02$ & $<0.1$ & 1 \\
\hline PPS4 & 2.2 & 0.23 & 0.09 & $<0.2$ & 3.14 & $<0.02$ & $<0.02$ & $<0.1$ & $<0.1$ \\
\hline PPS5 & 3.1 & 0.39 & 0.07 & 0.2 & 4.13 & $<0.02$ & $<0.02$ & $<0.1$ & 0.5 \\
\hline \multirow[t]{2}{*}{ PPS1 } & 4.4 & 0.39 & 0.2 & $<0.2$ & 3.74 & $<0.02$ & $<0.02$ & 0.1 & 2 \\
\hline & \multicolumn{9}{|c|}{ East Side } \\
\hline PPS7 & 28.2 & 0.38 & 0.09 & $<0.2$ & 7.35 & $<0.02$ & $<0.02$ & $<0.1$ & 6.2 \\
\hline PPS8 & 17.0 & 0.68 & 0.09 & 0.2 & 29.2 & $<0.02$ & $<0.02$ & $<0.1$ & 4.5 \\
\hline PPS9 & 7.1 & 0.54 & 0.07 & $<0.2$ & 11.8 & $<0.02$ & 0.03 & 0.2 & 4.6 \\
\hline PPS10 & 6.2 & 0.30 & $<0.06$ & $<0.2$ & 9.92 & $<0.02$ & $<0.02$ & $<0.1$ & 4.8 \\
\hline \multirow[t]{2}{*}{ PPS6 } & 3.6 & 0.69 & 0.07 & $<0.2$ & 11.5 & $<0.02$ & $<0.02$ & $<0.1$ & 2.4 \\
\hline & \multicolumn{9}{|c|}{ Duplicate } \\
\hline SSC1R & 1.9 & 0.10 & $<0.06$ & 0.2 & 4.38 & $<0.02$ & $<0.02$ & $<0.1$ & $\overline{0.8}$ \\
\hline PPS1R & 3.6 & 0.29 & $<0.06$ & 0.2 & 4.27 & $<0.02$ & $<0.02$ & $<0.1$ & 2 \\
\hline
\end{tabular}

